\title{
Current vulnerability in the Tri-National de la Sangha landscape, Cameroon
}

Tahia Devisscher

Sukaina Bharwani

Anne Marie Tiani

Charlotte Pavageau

Nadège Essoungou Kwack

Richard Taylor 



\section{Current vulnerability in the Tri-National de la Sangha landscape, Cameroon}

Tahia Devisscher

SEl International, Oxford

Sukaina Bharwani

SEl International, Oxford

Anne Marie Tiani

CIFOR

Charlotte Pavageau

CIFOR

Nadège Essoungou Kwack

CIFOR

Richard Taylor

SEl International, Oxford 
Working Paper 107

(c) 2013 Center for International Forestry Research

All rights reserved

Devisscher, T., Bharwani, S., Tiani, A.M., Pavageau, C., Kwack, N.E. and Taylor, R. 2013 Current vulnerability in the Tri-National de la Sangha landscape, Cameroon. Working Paper 107. CIFOR, Bogor, Indonesia.

Cover photo by Sukaina Bharwani

Road from Yokadouma to Mboy II.

CIFOR

Jl. CIFOR, Situ Gede

Bogor Barat 16115

Indonesia

$\mathrm{T}+62(251) 8622-622$

$\mathrm{F}+62(251) 8622-100$

E cifor@cgiar.org

\section{cifor.org}

Any views expressed in this publication are those of the authors. They do not necessarily represent the views of CIFOR, the authors' institutions or the financial sponsors of this publication. 


\section{Table of contents}

Acknowledgements $\quad$ v

Acronyms

Foreword $\quad$ vii

Summary viii

1 The landscape and study sites in Cameroon $\quad 1$

2 Conceptual framing of vulnerability $\quad 7$

3 Understanding current vulnerability: methodological approach 9

3.1 Preparatory phase 9

$\begin{array}{llr}3.2 & \text { Fieldwork } & 10\end{array}$

$\begin{array}{lll}3.3 & \text { Feedback workshop } & 10\end{array}$

4 Local perceptions of change $\quad 11$

5 Dynamic vulnerability and differentiated exposure $\quad 18$

5.1 Production System $\quad 19$

$\begin{array}{ll}5.2 \text { Role of forests } & 20\end{array}$

5.3 Livelihood diversification and trade $\quad 21$

$\begin{array}{ll}5.4 \text { Social capital for collective action } & 24\end{array}$

6 Conclusion: strengthening adaptive capacity $\quad 28$

7 References $\quad 30$ 


\section{List of figures and tables}

\section{Figures}

1 Study sites in the COBAM project vii

2 The TNS landscape 1

3 Mining concessions over forests and national parks 3

4 Development of community forests on the Cameroonian side of the TNS landscape 4

5 Community forests in the system of analysis 5

6 Trends in agriculture area in Mboy II and Mang since 1970 12

7 Perceived trends in forest resources since $1970 \quad 12$

8 Perceptions about the future of forests in Mboy II, Djalobekoe and Nampella 13

9 Climatic disturbances specified by surveyed households 16

10 Observed monthly rainfall totals 16

11 Total rainfall for the December-January-February period using 1979-2009

NCEP re-analysis data, Ouesso station 17

12 Rain days for February using 1979-2009 NCEP re-analysis data, Ouesso station 17

13 Total rainfall for April using 1979-2009 NCEP re-analysis data, Ouesso station 17

14 Production calendar 20

15 Effects from climate-related disturbances specified in the survey 21

16a Use and benefits from forest resources in Mboy II (men) 22

16b Use and benefits from forest resources in Mboy II (women) 22

17 Perceived benefits from forests in Mboy II 23

18 Main sources of revenue in the villages of Mboy II, Djalobekoe and Nampella 23

\section{Tables}

1 Population distribution in the TNS landscape 2

2 Forest cover loss derived from Landsat and MODIS satellite data 3

3 Community forests selected for the baseline assessment 6

4 Vulnerability dimensions and methods 9

5 Rhythm of deforestation before 1990, between 1990 and 2000 and after $2000 \quad 13$

6 Historical trendline of major events and threats 14

7 Description of climate-related disturbances $\quad 15$

8 Vulnerability matrix 18

9 Abundance and seasonality of main forest resources 23

10 Products traded in different locations and price differences 25

11 Summary of social infrastructure in the villages 26 


\section{Acknowledgements}

For the work conducted in the TNS landscape, we would like to thank Gerard Sindemo and his team at ROSE for their support. Special thanks also to the communities that were engaged in the study, for their support, openness and interest in this research. We would also like to thank Bruno Locatelli, Flore Ndong and Munoh Florence at CIFOR, for their help and advice in the preparation and implementation of the fieldwork. We are also grateful to Dr Ruth Butterfield and Monica Coll Besa at SEI, who supported the research and provided insightful comments to this document. We also would like to acknowledge Ivo Ekane, Martin Ahanda and Louis Lekegang at CIFOR for their patience during the fieldwork and their safe driving. 


\section{Acronyms}

APE

CAR

CFs

CFA

CIFAD

COBAM

CRY

DRC

EPC

FMUs

FSC

GICs

IPCC

MINFOF

NASA

NCEP

NTFP

OPADE

PADER

RBA

RFA

RICG

SDSU

SEBAC

SEI

SNV

TNS

UMD-CARPE

WWF

ZICGC
Association pour la Protection des Ecosystèmes Tropicaux et le Développement de la Sangha/Association des parents d'élève

Central African Republic

Community Forests

CFA franc

Centre International de Formation et d' Animation pour le Développement

Congo Basin: Synergies between Adaptation and Mitigation

Commune Rurale de Yokadouma

Democratic Republic of Congo

Eglise presbytérienne du Cameroun

Forest Management Units

Forest Stewardship Council

Initiatives de Gestion Communautaire

Intergovernmental Panel on Climate Change

Ministry of Forestry

National Aeronautics and Space Administration

National Centers for Environmental Prediction

Non-timber forest product

Organisation Panafricaine d'Appui au Développement et de l'Environnement

Programme d'Appui au développement Rural

Regional baseline assessment

Redevance Forestière Annuelle

Renforcement des Initiatives de Gestion Communautaire

South Dakota State University.

Société spécialisé dans l' exploitation et la transformation de bois au Cameroun

Stockholm Environment Institute

Netherlands Development Organisation

Tri-National de la Sangha

Central Africa Regional Program for the Environment

World Wildlife Fund

Zone d'intérêt cynégétique à gestion communautaire 


\section{Foreword}

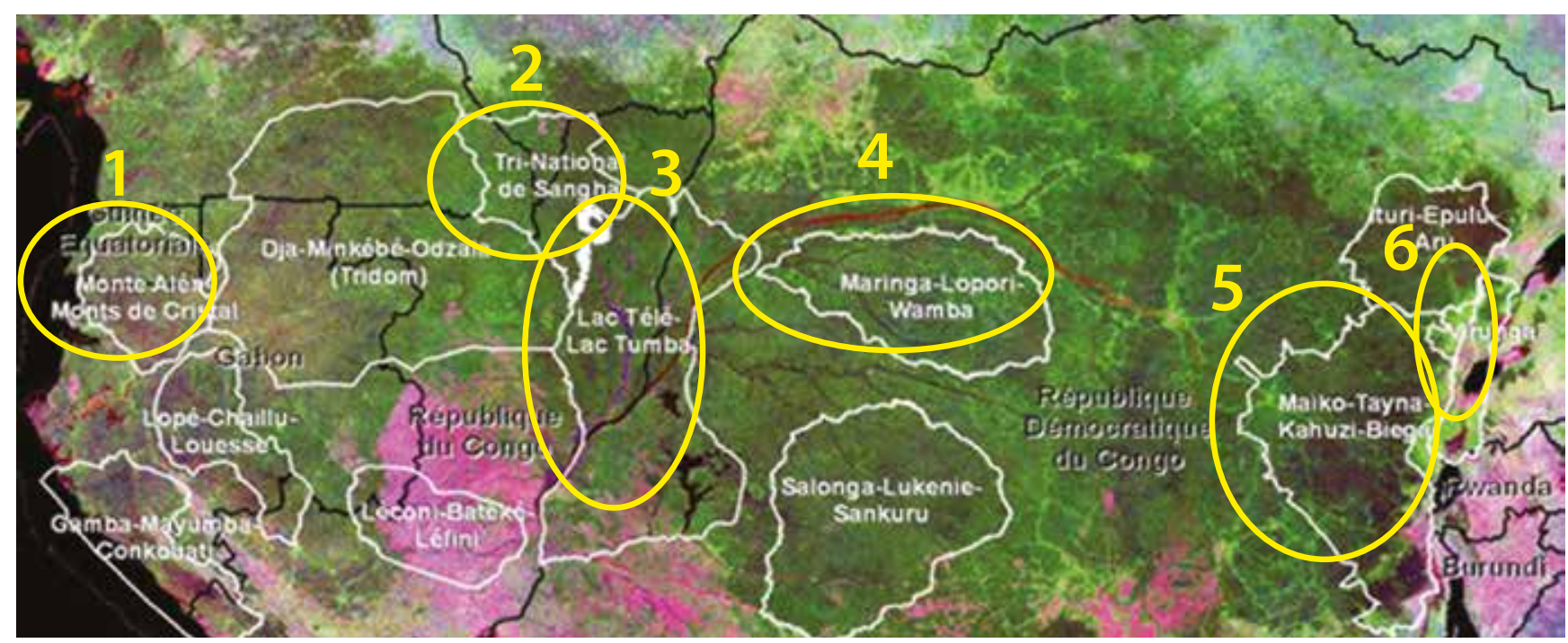

Figure 1. Study sites in the COBAM project

This working paper is an output of a regional baseline assessment (RBA) conducted in five landscapes of the Congo Basin under the Climate Change and Forests in the Congo Basin: Synergies between Adaptation and Mitigation (COBAM) project. ${ }^{1}$ The paper synthesises results generated in the Tri-National de la Sangha (TNS) landscape. The main objective of this RBA is to analyse current vulnerability of local communities to changes in climate in the context of multiple stresses and development processes in the sites. This assessment provides a basis for the evaluation of possible adaptation strategies that can be synergistic with mitigation efforts in the Congo Basin.

Five landscapes compose the RBA, and most of them span over more than one country of the Congo Basin. For practical purposes, the specific sites where the assessment was conducted are located in one country of each landscape in the following way: Tri-National de la Sangha (sites in Cameroon), Monte Alen-Monts Cristal (sites in Equatorial Guinea), Lac Tele-Lac Tumba and Maiko-Tayna-Kahuzi-Biega (sites in Democratic Republic of Congo) and Virunga (sites in Rwanda).

The RBA applies different dimensions of vulnerability as the lenses of analysis to study past trends and current conditions in the study sites.
The results will inform the second phase of the COBAM project; this will focus on scenario analysis to explore future vulnerability and potential climate adaptation options that are synergistic with mitigation efforts. In this regard, the RBA is a first step in identifying opportunities in the Congo Basin landscapes for the implementation of pilot actions that take advantage of co-benefits between adaptation and mitigation.

Many partners collaborated on the RBA. Researchers from CIFOR and SEI worked closely with local partners in each site to apply the different methods of the assessment.

This working paper starts with an overview of the TNS landscape and the sites selected for the RBA. It then presents the conceptual framing used for the vulnerability assessment and the methodology applied. The next two chapters present the results generated through the assessment. First, the local perceptions of change are described, including the main drivers of change. Second, dynamic vulnerability and differentiated impacts are discussed, as perceived by local communities. The paper concludes with entry points to enhance communities' adaptive capacity and some considerations for further analysis of future vulnerability and potential adaptive strategies. 


\section{Summary}

The study of the current vulnerability of villages in the Tri-National de la Sangha Landscape, Cameroon, creates the basis to evaluate future vulnerability and identify possible adaptation strategies that could be synergistic with mitigation efforts in the Congo region. In the assessment, important social, ecological and economic processes were explored using a participatory approach; different dimensions of vulnerability were applied as the lenses for analysis. The following are key insights gained through this assessment.

Vulnerability is dynamic in nature. The assessment shows important social, ecological and economic changes over the past decades, which have shaped the vulnerability of villages in the project site. Four decades ago, villages had small production fields and were surrounded by forests with abundant resources. Villagers state that, over time, competition for productive land and forest resources has degraded forests around the villages and increased the fragility of local livelihoods; as resources become scarcer, the population keeps growing and uncertainty about rainfall patterns increases. Villagers recognise a number of threats that can affect their livelihoods. Climate-related disturbances combine with a myriad of other threats and current conditions to shape the vulnerability of villages in the study sites. Among the main climate-related disturbances, villagers mentioned intense drought, changing seasons and strong winds.

Vulnerability is different for different groups. Based on the analysis, different groups, natural resources and activities are affected differently by different climatic disturbances. Children and the elderly seem to be the most vulnerable social groups in the villages. Agriculture is the most exposed and affected activity by adverse climate-related disturbances such as drought and changing seasons. Some forest resources are also vulnerable but to a lesser extent; in some cases non-timber forest products (NTFPs) have benefited from changes in weather patterns.

\section{Villages as a whole are highly vulnerable to a} changing climate. Most of the households in the villages depend on agriculture for their subsistence and economic development. Shifts in the seasons and increased unpredictability of rainfall patterns have led to adverse impacts on agricultural production, and hence food security and the local economy.
Increasing agricultural land to compensate for losses has put more pressure on other natural resources on which the villages depend. Villagers recognise the uncertainty in their ability to predict wet and dry periods and to follow the 'traditional' production calendar for their activities. Increased climate variability and uncertainty seem to be one of the main disturbances shaping current vulnerability in the villages.

\section{Livelihood diversification is a current strength.} Villages depend on several activities for their subsistence and economic base. Most of these activities relate to the management or extraction of natural resources through agriculture, collection of NTFPs, logging and mining. Although villagers produce mainly for self-consumption, products such as cacao, manioc and plantain and, to a lesser extent, bushmeat are important sources of household income. Villages are generally well connected to markets where groups of households sell their products jointly. Agriculture is the main base of their economy. NTFPs play a less important role for the local economy, mainly because their commerce is not well organised yet. Instead, NTFPs seem to be important safety nets in periods of scarcity and stress.

Social capital is weak but needed. In most villages, collective action to maintain social infrastructure is weak, denoting poor management for the common good of the village as a whole. In contrast, collective action is present when specific household groups combine efforts to improve their agricultural practices and trade. External interventions from elites or NGOs differ in the villages; villages closer to Yokadouma seem to have received more external support than distant villages. Private investment from companies settling in the area can play an important role for labour creation when locals are hired instead of migrants; however, they do not necessarily contribute to the welfare of the villages as a whole.

Most of the insights gained through this vulnerability assessment will be combined with more in-depth research to explore future vulnerability and identify synergies between mitigation and adaptation in the sites. Results from further analysis will generate recommendations to inform decision-making and planning at the local and national levels across the Congo Basin countries. 


\section{The landscape and study sites in Cameroon}

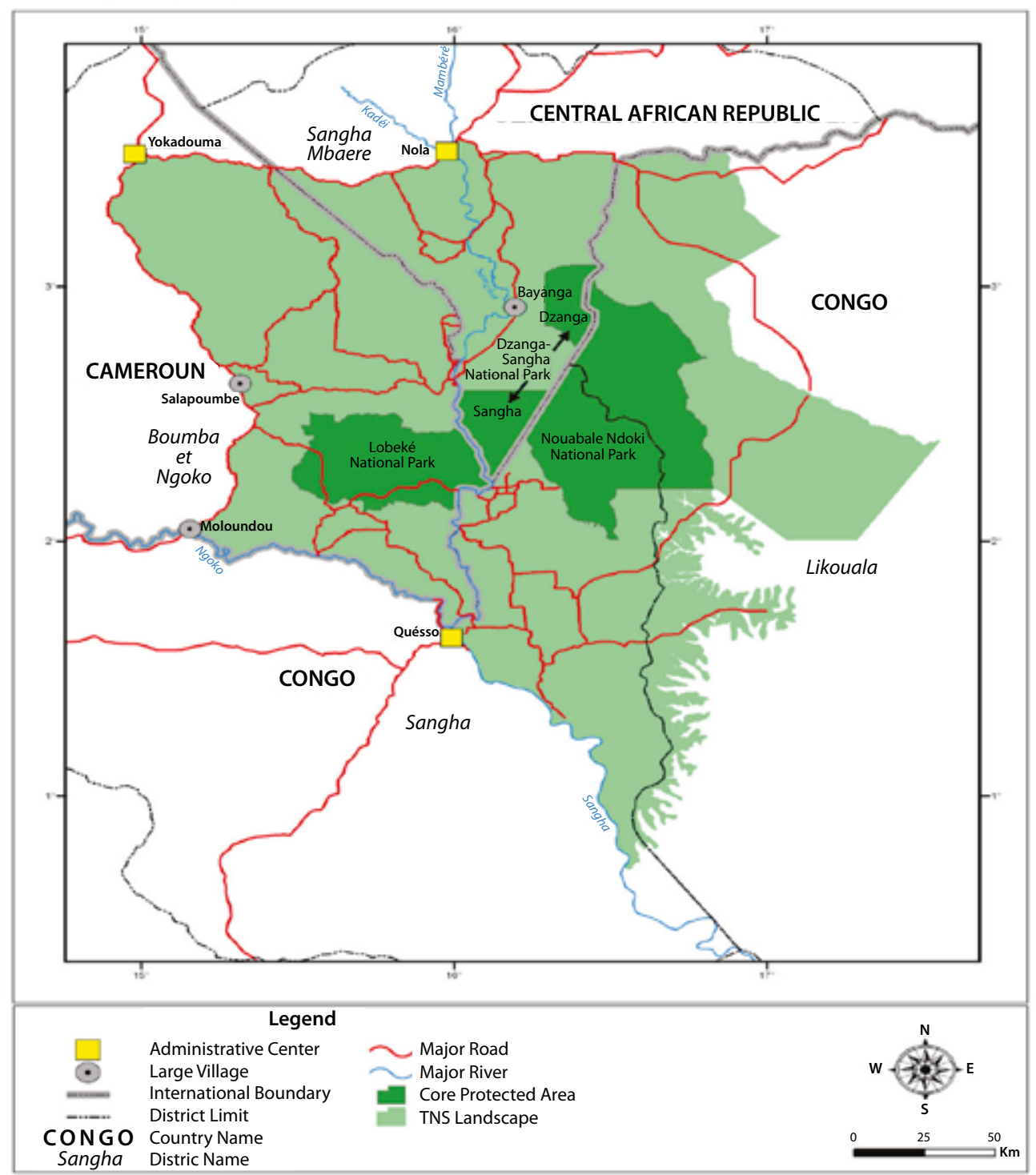

Figure 2. The TNS landscape

Source: Usongo and Nzooh (2008)

The Tri-National de la Sangha (TNS) landscape covers $43936 \mathrm{~km}^{2}$ and spans over four districts ${ }^{2}$ located in three countries: Cameroon, Central African Republic (CAR) and Democratic Republic of Congo (DRC). The landscape comprises three national parks: Lobéké (Cameroon), Nouabalé-Ndoki (DRC) and Dzanga- Ndoki (CAR) (see Figure 2). The areas surrounding the national parks, around 3751800 ha, have multiple uses with zones for logging concessions, community use and professional hunting (Usongo and Nzooh 2008).
Important progress has been made in land-use planning within the TNS landscape, although some overlaps between different land uses need solutions. A number of national parks have management plans approved, as do several forest concessions and wildlife zones. Furthermore, several forest concessions have approved management plans and some forestry companies are part of sustainable certification schemes. By 2008, 1051600 ha of 3388803 ha of forest concessions had been certified under the Forest Stewardship Council (FSC) (Usongo and Nzooh 2008). 
The TNS economy is greatly based on extractive exploitation of forest resources. In the formal sector, the main resource is timber. In the less formal sector, there is extraction and trade of several mineral ores (e.g. diamonds, gold and aluminum), bushmeat, palm wine, fish and other non-timber forest products (NTFPs). Agricultural production is also important, mainly for subsistence but also for commerce. The impacts of this extractive economy on the socio-economic conditions and activities in the villages are not easy to quantify as they are diffuse and vary over time. However, it is possible to quantify low levels of basic services and high levels of poverty. In general, social services, such as education and health, benefit little from the incomes generated from forest exploitation. Although some local people find employment in this industry, most jobs go to high-skilled workers who come from abroad (Usongo and Nzooh 2008).

The population density of the TNS landscape is estimated at five individuals per $\mathrm{km}^{2}$ with a total population of around 200000 . Approximately two-thirds of the populations in the more industrialised towns are immigrants who work for the forest concessions or Forest Management Units (FMUs). Table 1 summarises the human population densities and distributions in major towns and villages within the TNS landscape.

In terms of vegetation-cover change in the TNS landscape, primary forest has been heavily exploited in many areas mainly by commercial logging. According to Usongo and Nzooh (2008), the only exceptions are un-logged forests of the Dzanga-Ndoki zone and part of northern Congo. The estimated proportion of forest loss for the period $1990-2000$ is about $0.2 \%$, which is relatively low when compared to other areas in the Congo Basin (Table 2). However, this rate increased to $0.32 \%$ between 2000 and 2005 mainly due to factors such as increased allocation of forest concessions and expanding slash-and-burn agricultural practices in the region (Usongo and Nzooh 2008).

The main threats to biodiversity conservation within the TNS landscape are hunting and commercial trade of bushmeat, unsustainable commercial logging, uncontrolled mining, ivory trade and the capture and trade of unique wildlife like the African Grey Parrot (Usongo and Nzooh 2008). The overlap of different land uses is also an issue and has often led to conflicts in the area. Figure 3 shows the overlap between mining concessions, forests and national parks in the Cameroon side of the TNS landscape.

Four Community Forests (CFs) were selected for the baseline assessment in the Cameroonian side of the TNS landscape. In Cameroon, Community Forests are forested areas in 'non-permanent forest zones' managed under agreement between a group of villages and the forest administration; the parties pursue sustainable extraction of wood for the social benefit of the participating villages (see article 31.5

Table 1. Population distribution in the TNS landscape

\begin{tabular}{|c|c|c|c|c|c|c|c|}
\hline \multirow[t]{2}{*}{ Country } & \multicolumn{2}{|c|}{ Administrative centres } & \multicolumn{2}{|c|}{ Industrial towns } & \multicolumn{2}{|c|}{ Rural villages (all) } & \multirow{2}{*}{\begin{tabular}{|c|} 
Pygmies \\
Population
\end{tabular}} \\
\hline & Name & Population & Name & Population & Name & Population & \\
\hline \multirow[t]{4}{*}{ Cameroon } & Yokadouma & 10,000 & Lokomo & 2,700 & $\begin{array}{l}\text { Sous-préfecture } \\
\text { Yokadouma }\end{array}$ & 24,300 & 3,400 \\
\hline & Molondou & 3,200 & Libingo/Bela & 4,300 & $\begin{array}{l}\text { Sous-préfecture } \\
\text { Moloundou }\end{array}$ & 16,100 & 7,100 \\
\hline & & & Kika & 1,400 & & & \\
\hline & & & Ngolla 35 & 1,150 & & & \\
\hline \multirow[t]{2}{*}{ CAR } & Nola & 37,000 & Bayanga & 4,000 & $\begin{array}{l}\text { Dzangha-Sangha } \\
\text { Special Reserve }\end{array}$ & 2,250 & 1,150 \\
\hline & & & Salo & 2,000 & Outside the Reserve & 8,000 & 3,000 \\
\hline \multirow[t]{5}{*}{ Congo } & Ouesso & 22,000 & Kabo & 3,000 & FMU Kabo & 650 & \\
\hline & & & Pokola & 14,500 & FMU Pokola & 2,500 & $\begin{array}{c}1,700 \\
\text { (50\% in Pokola) }\end{array}$ \\
\hline & & & & & FMU Toukoulaka & 2,300 & 900 \\
\hline & & & & & FMU Loundougou & 6,000 & 2,700 \\
\hline & & & & & FMU Mokabi & 4,000 & \\
\hline Total & 72,200 & & 33,050 & & & 66,100 & 19,950 \\
\hline
\end{tabular}




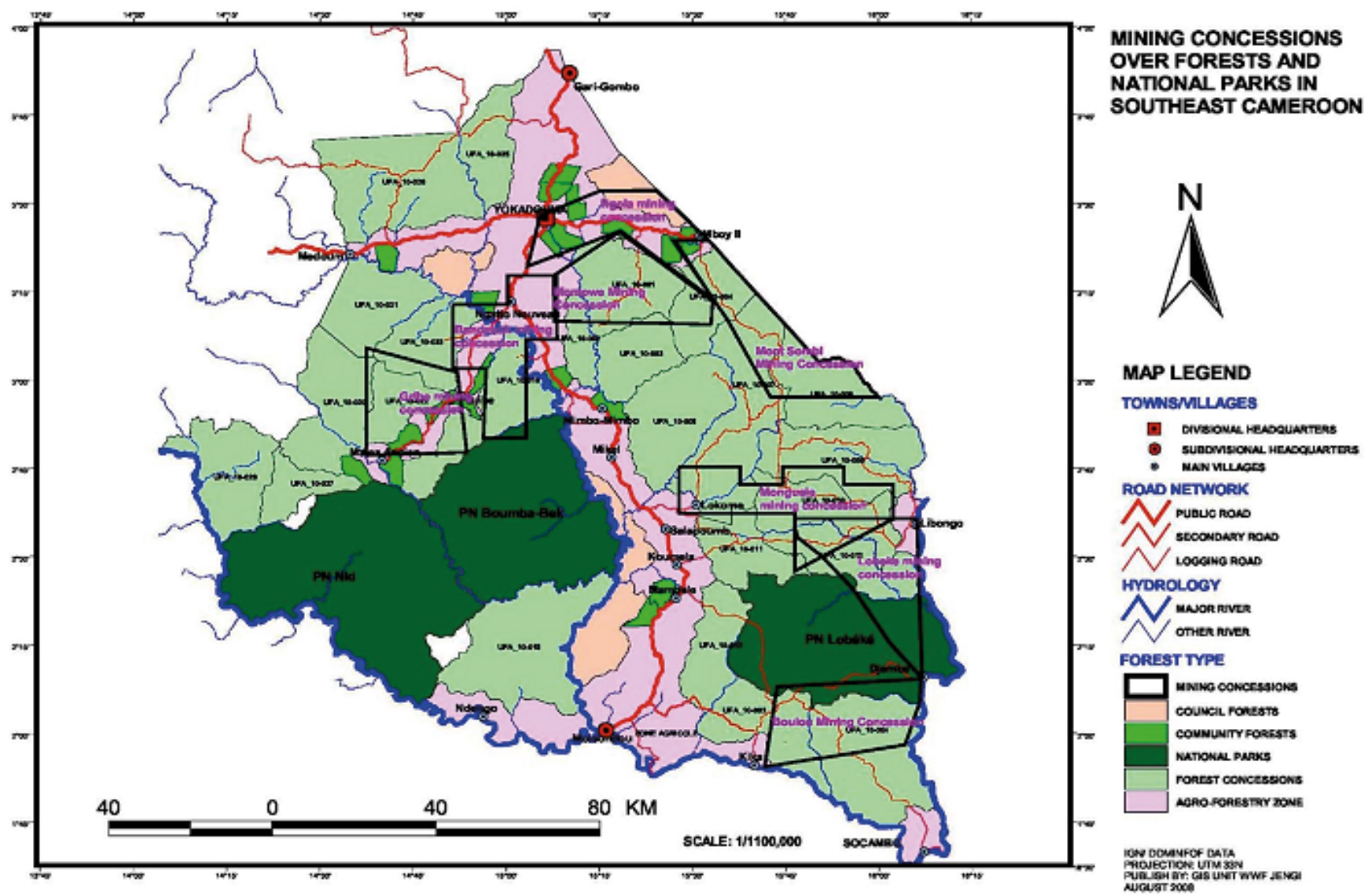

Figure 3. Mining concessions over forests and national parks

Source: WWF Cameroon (2008)

Table 2. Forest cover loss derived from Landsat and MODIS satellite data (1990 - 2005)

\begin{tabular}{lccccc}
\hline & \multicolumn{2}{c}{ Forest area } & \multicolumn{2}{c}{ Forest area loss } \\
\hline Year & 1990 & 2000 & 2005 & $1990-$ & $2000-$ \\
& & & & 2000 & 2005 \\
\hline $\mathrm{Km}^{2}$ & 42820 & 42743 & 42608 & 77 & 135 \\
\hline Percentage & & & & $18 \%$ & $32 \%$ \\
\hline
\end{tabular}

Sources: SDSU, UMD-CARPE, NASA

of the Forest Law No 94). A Community Forest cannot exceed 5000 ha in area. To start activities in a CF, management entities need to collectively develop a Simple Management Plan for approval by the Ministry of Forestry (MINFOF). Exploitation of fauna in CFs is defined by a management plan developed with the administration in charge of fauna and forests (see article 95 of the Forest Law No 94). In the non-permanent zone, fauna is locally managed by the 'Zone d'intérêt cynégétique à gestion communautaire' (ZICGC).

Currently, eight CFs are officially established on the Cameroonian side of the TNS. However, if CFs in different stages of development are counted, the total reaches 15 . Community Forests have multiplied since 2000, as well as reserves and forest concessions (see Figure 4).

The four Community Forests selected for the study are located in two road axes linked to the administrative centre of Yokadouma (see Figure 5). The CFs selected for the baseline assessment had to be representative enough to allow an extrapolation of the results for the rest of the Cameroonian side of the TNS landscape. Hence, five criteria were used to select the sites:

- Location: the CF has to be located within the geographical boundaries of the TNS landscape

- State of activity: the CF has to be functioning

- Size and diversity of the community of villages managing the CF: the population managing the CF has to be diverse and involve several social and ethnic groups

- Distance from urban areas: distance to the urban centre (Yokadouma) needs to vary

- Accessibility and transitability: the CF needs to be easily accessible by road 


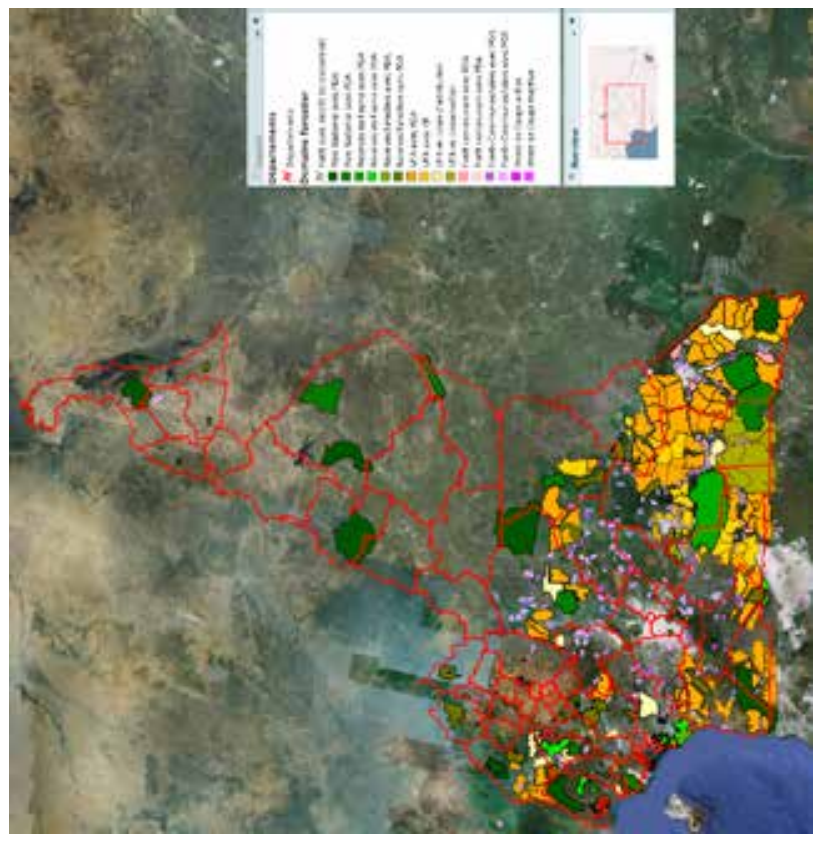

응

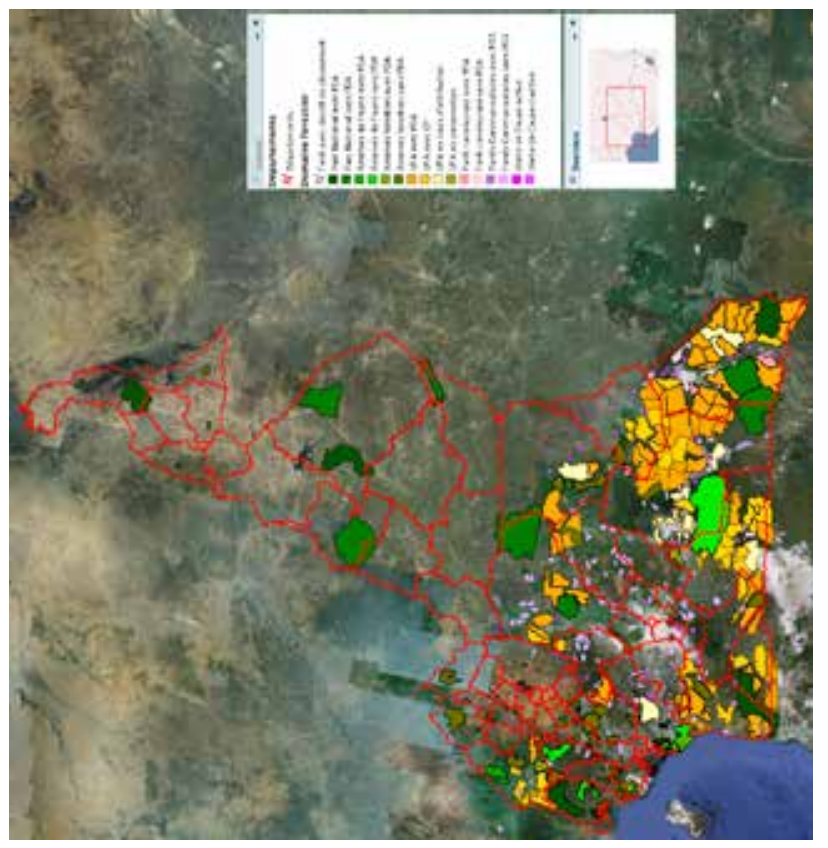

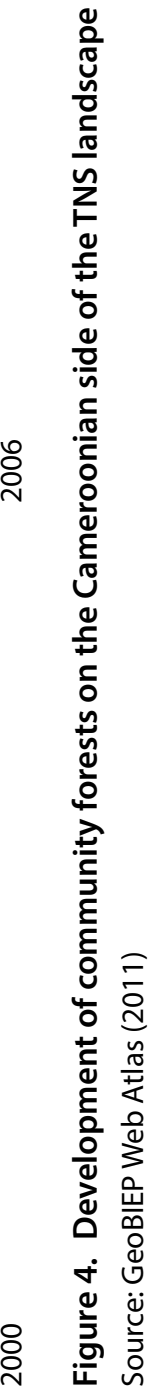

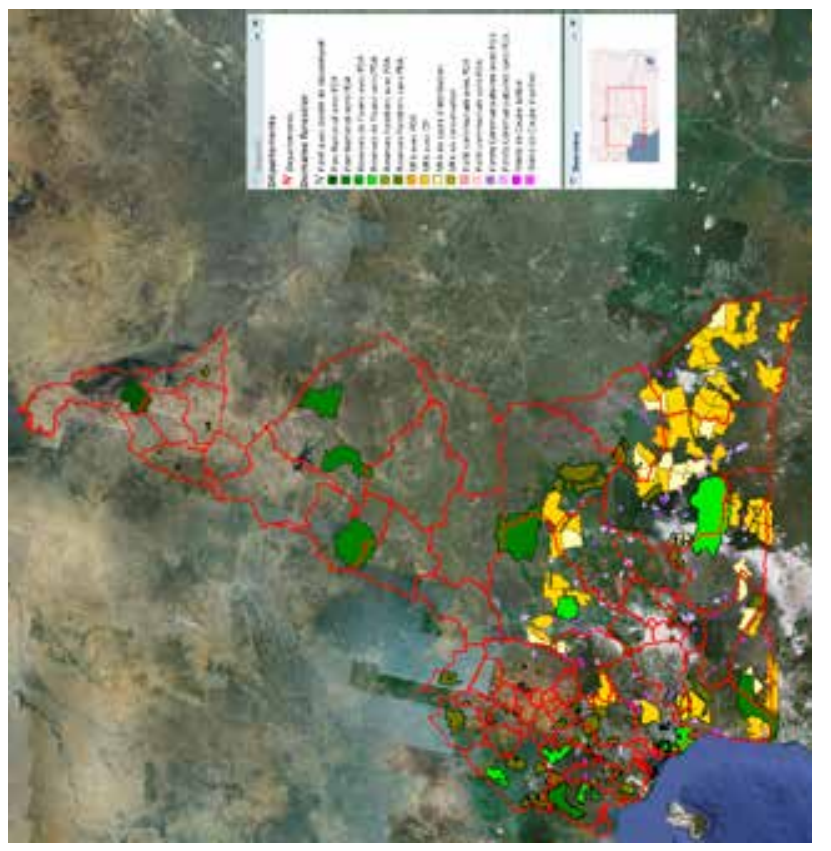




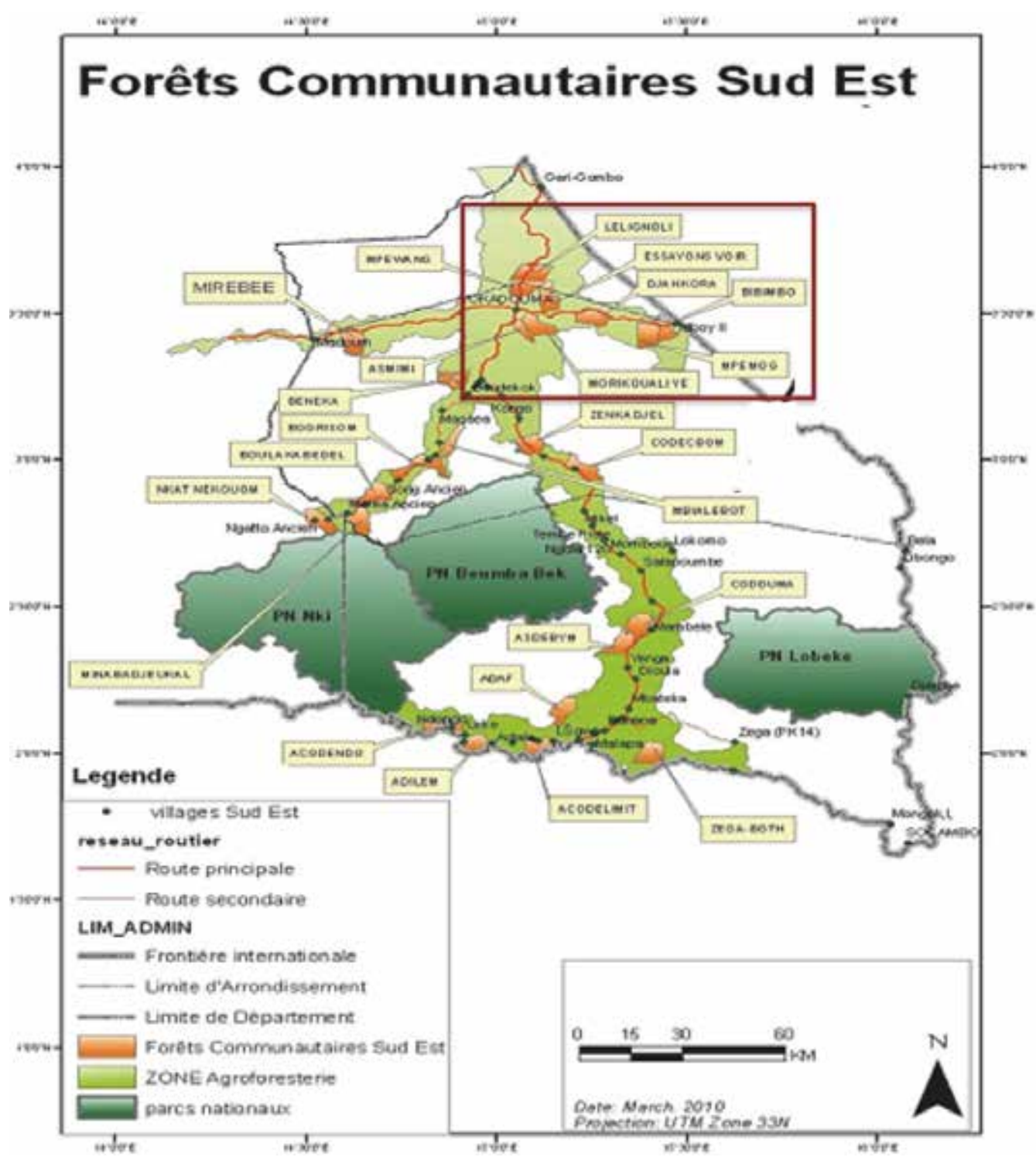

Figure 5. Community forests in the system of analysis

Source: WWF Cameroon (2010)

In total, 13 villages are clustered in the four study CFs, 12 of which are located along the west-east road axis that links Yokadouma with Mboy II, a village located at the border with the Central African Republic. Table 3 provides an overview of the selected CFs. The villages engaged in the baseline assessment are: Mboy II (53 km from Yokadouma), Massiembo (43 km), Mang (40 km), Nampella (30 $\mathrm{km})$, Bompelo $(38 \mathrm{~km})$, Djalobekoe $(7 \mathrm{~km})$ and Mendoungue $(6 \mathrm{~km})$.

The history of villages' settlement and development is closely related to road construction. On the Yokadouma-Mboy road axis, the first settlements relate to migration waves during German colonial times in the 1920s. The Mpiemo is an ethnic group coming from the Central African Republic that first settled in the border and created the village of Mboy. For some villagers, this migration was driven by tribal wars, while others wished to move closer to the German settlements in the locality (Yokadouma was a German base at that time). While some Mpiemo people crossed the Sangha River and established Mboy, others continued for $15 \mathrm{~km}$ to create the villages of Mang, Massiembo and Bompelo. In the 1950s, a small group of Mpiemo left Mboy to be closer to Yokadouma and created the village of Djalobekoe. A few years before the independence of Cameroon in 1960, Baka groups joined these villages, though their relative proportion in the villages varies. With time, other ethnic groups joined the villages through marriage ties. For example, Muslim groups arrived in the mid 1970s and have since continued to grow in number. Central Africans have also been migrating to this area since 2000 , mainly through marriage ties but also in search of new life opportunities. 
Table 3. Community forests selected for the baseline assessment

\begin{tabular}{|c|c|c|c|c|c|c|}
\hline $\begin{array}{l}\text { Community } \\
\text { Forest }\end{array}$ & Villages & $\begin{array}{l}\text { Management } \\
\text { entity }\end{array}$ & Clans & Sur-face & $\begin{array}{l}\text { Distance from } \\
\text { Yokadouma }\end{array}$ & Road Axis \\
\hline Bibimbo II & Mboy II & $\begin{array}{l}\text { GIC Biweigui } \\
\text { Bi Mboy II }\end{array}$ & $\begin{array}{l}\text { Mpiemo } \\
\text { Baka }\end{array}$ & 1560 ha & $53 \mathrm{~km}$ & $\begin{array}{l}\text { West-East } \\
\text { (Yokadouma- } \\
\text { Mboy2/ CAR) }\end{array}$ \\
\hline Mpiemog & $\begin{array}{l}\text { Bompelo } \\
\text { Massiembo } \\
\text { Mang } \\
\text { Nampella }\end{array}$ & GIC Mpiemog & $\begin{array}{l}\text { Mpiemo } \\
\text { Baka }\end{array}$ & 5500 ha & $38 \mathrm{~km}$ & $\begin{array}{l}\text { West-East } \\
\text { (Yokadouma- } \\
\text { Mboy2/ CAR) }\end{array}$ \\
\hline Morikoualye & $\begin{array}{l}\text { Djalobekoe } \\
\text { Nyabonda } \\
\text { Limoe } \\
\text { Mondong } \\
\text { Mohevéa } \\
\text { Momotegona } \\
\text { Momolegue }\end{array}$ & GIC Morikoualye & $\begin{array}{l}\text { Mpiemo } \\
\text { Baka }\end{array}$ & 5000 ha & $7 \mathrm{~km}$ & $\begin{array}{l}\text { West-East } \\
\text { (Yokadouma- } \\
\text { Mboy2/ CAR) }\end{array}$ \\
\hline Asmimi & Mendoungue & GIC ASMIMI & $\begin{array}{l}\text { Poupong } \\
\text { Baka }\end{array}$ & 2600 ha & $4 \mathrm{~km}$ & $\begin{array}{l}\text { North-South } \\
\text { (Yokadouma- } \\
\text { Moloundou) }\end{array}$ \\
\hline
\end{tabular}

In the Yokadouma-Moloundou Axis, the villages have a different history. Mendoungue, the only village in this axis considered for the baseline assessment, was also created during the German colonial period. This village was first occupied by Poupong people, who left what is today the DRC so they could live close to the German settlement in Yokadouma.

The main natural resources identified by the villagers are rivers, primary forests, secondary forests, swamps and fallow. The Community Forests managed by the villages consist of both primary and secondary forest. Both types of forest are used for hunting (e.g. hare, deer, wild boar, porcupine, palm rat, hedgehog, gorilla), fishing and collection of NTFPs (e.g. Koko, wild mango, Djanssang), as well as logging. Secondary forests are also used for growing cash crops such as cocoa, coffee and NTFPs (e.g. Andok, Koko, Djanssang), and subsistence crops such as maize, cassava and plantain. In some cases, rivers close to the villages serve as the boundaries demarcating the land and are used for shrimp collection and fishing. Villagers know well the limits of the village area and the CFs. In some cases, such as Mboy II and Mang, there are border conflicts with Forest Management Units (FMUs). According to the villagers, neighbouring FMUs have expanded into the village territories over time, encroaching primary and secondary forests.

Various types of land distribution could be seen within the Community Forest and surrounding communal areas, from individual and household to clan and village level. There is no open access resource in the area; permission to use land and other natural resources should be requested in all cases and the right of access varies according to heritage and marriage. 


\section{Conceptual framing of vulnerability}

Scholars from different knowledge domains and diverse communities of practice conceptualise vulnerability in very different ways. This is mainly because different research traditions have their own way to relate to concepts and meanings. Kasperson and Kasperson (2005) conclude there is no single concept of vulnerability that would fit all assessment contexts and purposes. The choice of definition may depend on its suitability for a particular vulnerability and its interpretation for policy or action

(Downing et al. 2005).

Before being introduced to the climate change community in the 1990s, the term vulnerability was used by the natural-hazard community. Since its adoption, the definition and interpretation of vulnerability have evolved, reflecting the different purposes for which vulnerability has been assessed. Initial vulnerability studies focused on the assessment of impacts to support climate mitigation efforts. Later studies assessed vulnerability focusing on people, livelihoods, sectors and economies to identify climate adaptation options and strategies.

The existence of diverse concepts of vulnerability has become particularly problematic in the climate change field, which is characterised by close collaboration between scholars from many different disciplines and communities of practice (Fussel 2007). In the climate change community, 'vulnerability' commonly refers to the capacity of a system to be affected by a hazard (Turner $e t$ al. 2003). This notion closely relates to the vulnerability definition suggested by the Intergovernmental Panel on Climate Change (IPCC): 'climate vulnerability is the degree to which a system is susceptible to, or unable to cope with, adverse effects of climate change, including climate variability and extremes. Vulnerability is a function of the character, magnitude and rate of climate variation to which a system is exposed, its sensitivity and its adaptive capacity' (McCarthy et al. 2001).

According to the IPCC definition, the potential impact of climate change on a system results from exposure and sensitivity. Sensitivity refers to the degree to which a system will be affected by a change (e.g. in climate), either positively or negatively, while exposure is the nature and degree to which a system is exposed to a potential hazard or threat (Locatelli et al. 2010). These two almost inseparable properties depend on the interaction between the characteristics of the system and on the attributes of the hazard (Smit and Wandel 2006). Many of the determinants of sensitivity are similar to those that shape or constrain a system's adaptive capacity, which is the ability of a system to adapt, cope or recover from the effects of hazardous conditions (Fussel 2007).

Several authors from different disciplines have attempted to develop conceptual frameworks for vulnerability assessments in the context of global environmental change (see Brooks 2003; Luers et al. 2003; Downing and Patwardhan 2004; Fussel 2004; Metzger et al. 2005). While these frameworks provide useful guidance, tensions remain in how vulnerability is viewed, communicated and used. Despite their differences, each aforementioned vulnerability framework captures dimensions of vulnerability in one way or another.

Issues may arise from multiple meanings and interpretations of vulnerability. Moreover, a specific assessment framework could lock analysis into a particular way of thinking that does not necessarily capture all the concepts of vulnerability. Below, for the sake of clarity, the authors identify the vulnerability dimensions they chose as lenses for analysis:

System and exposure units: The system of this analysis is defined as 'landscapes in the Congo Basin'. It concerns a coupled socio-ecological system; a population or social group and its social arrangements; an economic sector; a geographical region or location; or a natural ecosystem (Fussel 2007). Vulnerability (including adaptive capacity) is context-specific, although its temporal and spatial scales are not independent or separate (Smit and Wandel 2006). The system identifies valued attributes that could be threatened by its exposure to a threat (Fussel 2007).

Dynamic processes: Vulnerability assessments can correspond to present conditions (i.e. the baseline conditions of vulnerability) and these conditions can 
be extended to the future as a reference scenario of vulnerability or possible vulnerabilities (Fussel 2007). In general, the time period considered for vulnerability assessments to anthropogenic climate change covers at least two decades into the past and five decades into the future.

Vulnerability is a dynamic process, changing on a variety of inter-linked temporal and spatial scales. Vulnerability is rooted in the actions and multiple attributes of human actors (Downing et al. 2005), as well as in the functioning and flows of ecosystems (Locatelli et al. 2010), reflecting the non-linear interactions and feedbacks that shape the vulnerability of a system. Vulnerability is constructed simultaneously on more than one scale and can involve rapid changes, often with discontinuities that can break a trend. While some change processes are slow (e.g. ecological succession), some can be fast (e.g. forced migration) and unexpected (e.g. death of a pivotal political leader), denoting the interplay between periods of gradual and abrupt change in a system.

Multiple threats: Threats are potentially damaging influences or disturbances that interact with a system's existing processes and structures. A system can be affected by multiple threats, which can include ecological, social, physical, economic and political change, as well as technological change and innovation. (RA 2010). Multiple threats are inherent in integrating vulnerability of peoples, livelihoods and systems (Downing et al. 2005). Threats can occur as discrete events in time, referred to as a shock or perturbation to the system; they can also occur as gradual change such as stress or pressure on the system (RA 2010). A threat is generally but not always external to the system under consideration; it can also be part of its natural variability.

Differentiated exposure: Different exposure units (i.e. components of the system) are exposed to, experience or anticipate threats in different ways (Downing et al. 2005). In this sense, vulnerability is more specific than general. It relates to specific exposure units (e.g. specific economic activities, livelihoods or social groups) and threats (e.g. drought, flood, sea-level rise). Vulnerability is unlikely to be the same for all threats, even if all are climate-related (e.g. increasing temperature, floods, sea-level rise, droughts, etc.). As a result, it is difficult to produce a single composite index that reflects the aggregate exposure of all the exposure units to all of the potential threats (Downing et al. 2005).

Social capital and collective action: In the context of resource-dependent livelihoods, social capital can facilitate adaptive capacity by exploring its interactions with natural capital (Crona and Bodin 2010). Both social capital and the social dynamics of adaptive capacity are defined by the ability to act collectively; this, in turn, involves understanding the interdependence of actors through their relationships with each other, with the institutions in which they reside and with the resource base on which they depend (Adger 2003). The ability to act collectively also depends on shared understandings and a common vision (Ostrom 2005).

Social networks drive and bound vulnerability in social, economic, political and environmental interactions (Bodin and Crona 2009; Crona and Bodin 2010). In times of rapid change, social networks can facilitate individual and collective change (Rayner and Malone 2001) and provide arenas for novelty, innovation and enhanced flexibility (Gunderson et al. 1995). These networks are often described as an asset of an individual or a society; however, they may also imply constraints (e.g. by including dependent relationships) (Cleaver 2005). Social networks are sometimes associated with the concept of social capital. Social capital involves relations of trust, reciprocity and exchange, as well as the evolution of common rules and the role of networks for collective action (Adger 2003). It also involves resources and assets that serve a common use, such as education or health centres, roads or religious centres. 


\section{Understanding current vulnerability: methodological approach}

The vulnerability assessment focused mainly on current vulnerability, which includes an analysis of past trends and coping strategies, as well as present conditions. The analysis also centred mainly on the social aspects of vulnerability, understanding vulnerability as processes rooted in the actions of human actors and the interactions with the nature base on which these actors depend. The dimensions of vulnerability described in the previous section framed the assessment, which largely applied a participatory approach.

A set of participatory methods was used to understand local perceptions and elicit information for the analysis. The time period considered for the current vulnerability analysis covers at least three decades — from the 1970s to present. This was important in order to understand multiple threats that may have previously affected the villages; it also helped understand processes of change in terms of coping mechanisms, social dynamics (e.g. formation of associations or institutions) and ecological dynamics (e.g. degradation or maintenance of forest resources). When possible, local perceptions were compared to observed climate data at station level. The comparison between different types of data provided insights into the understanding of perceptions and was useful to characterise the variability of environmental parameters. Table 4 lists methods applied to analyse the different dimensions of vulnerability. The baseline assessment comprised three main phases: 1) preparatory phase, 2) fieldwork and 3) feedback workshop.

\subsection{Preparatory phase}

The preparatory process involved a literature review of documents and data relevant to the TNS landscape, as well as the development of survey questions and participatory exercises to apply with communities in the study site. It also required liaison with key stakeholders. ROSE, a network of local NGOS in Yokadouma, also played an important role in the preparatory stage to identify key stakeholders and prepare the venue for training on the participatory methods we designed to use. This

Table 4. Vulnerability dimensions and methods

\begin{tabular}{|c|c|c|c|}
\hline $\begin{array}{l}\text { Vulnerability } \\
\text { dimension }\end{array}$ & Method & Site & Participants \\
\hline $\begin{array}{l}\text { System and } \\
\text { exposure units }\end{array}$ & $\begin{array}{l}\text { Literature review, village } \\
\text { profiles, resource mapping }\end{array}$ & $\begin{array}{l}\text { TNS landscape, Mboy } \\
\text { II, Mang, Djalobekoe, } \\
\text { Mendoungue }\end{array}$ & $\begin{array}{l}\text { ROSE*, Village leaders of Mboy II, } \\
\text { Mang, Djalobekoe, Mendoungue }\end{array}$ \\
\hline $\begin{array}{l}\text { Dynamic } \\
\text { processes }\end{array}$ & $\begin{array}{l}\text { Trends analysis, forest-people } \\
\text { interaction analysis, trade and } \\
\text { flows analysis, production } \\
\text { system analysis, surveys }\end{array}$ & $\begin{array}{l}\text { Mboy II, Mang, Djalobekoe, } \\
\text { Mendoungue (group } \\
\text { exercises), Mboy II, Nampella, } \\
\text { Djalobekoe (surveys) }\end{array}$ & Groups of villagers \\
\hline Multiple threats & $\begin{array}{l}\text { Historical disturbance analysis, } \\
\text { climate-related disturbance } \\
\text { analysis,, surveys }\end{array}$ & $\begin{array}{l}\text { Mboy II, Mang, Djalobekoe } \\
\text { (group discussions), Mboy } \\
\text { II, Nampella, Djalobekoe } \\
\text { (surveys) }\end{array}$ & Groups of villagers \\
\hline $\begin{array}{l}\text { Differential } \\
\text { exposure }\end{array}$ & $\begin{array}{l}\text { Vulnerability-exposure } \\
\text { analysis, seasonal calendar and } \\
\text { product system analysis, forest } \\
\text { use and benefits analysis }\end{array}$ & Mboy II, Mang, Djalobekoe & $\begin{array}{l}\text { Groups of villagers (women and } \\
\text { men in separated groups) }\end{array}$ \\
\hline $\begin{array}{l}\text { Social capital } \\
\text { and collective } \\
\text { action }\end{array}$ & $\begin{array}{l}\text { Social capital analysis, social } \\
\text { network mapping, coping } \\
\text { strategies analysis }\end{array}$ & $\begin{array}{l}\text { Mboy II, Mang, Djalobekoe, } \\
\text { Mendoungue }\end{array}$ & $\begin{array}{l}\text { ROSE*, groups of villagers, } \\
\text { village leaders of Mboy II, Mang, } \\
\text { Djalobekoe and Mendoungue }\end{array}$ \\
\hline
\end{tabular}

* ROSE is a network of local NGOs based in Yokadouma. They are the local partner supporting the baseline assessment in the TNS landscape. 
training, which involved village chiefs, representatives of local NGOs and forest community committees, helped to test and refine methods before their implementation in the sites. Local authorities were also informed about the research work and objectives during this first phase.

\subsection{Fieldwork}

The fieldwork applied participatory methods, engaging in the process different social groups that live in the selected communities. Working in collaboration with ROSE, information and knowledge was gathered through focus group discussions, participatory observation, participatory mapping and surveys conducted in the sites. Each method involved a different number of participants. The focus group discussions were conducted in Mboy II, Djalobekoe, Mang and Mendoungue and involved mixed groups of women, men, elderly and young participants. In some instances, participants were divided into homogeneous groups of men and women to gain more balanced participation from both genders.

Generally, village chiefs and local partners selected the participants for the participatory exercises, which were generally representative of different ethnic groups in the sites. In addition, surveys were conducted in 40 households per site over three sites (Mboy II, Nampella, Djalobekoe) resulting in a sample of 120 households. Two surveys were applied (120 households each): one covering vulnerability perceptions, the other focusing on forest governance. Before we conducted surveys in the sites, local supporters who were trained on the sampling technique and the survey questions applied the surveys.

\subsection{Feedback workshop}

After completing the fieldwork on all sites, a workshop fed back results obtained from the participatory research. This workshop, which validated the exercise, involved mainly village chiefs, local NGO representatives and key stakeholders from the sites engaged in the fieldwork. The workshop was structured in three parts:

- Presentation of results and validation

- Introduction to concepts of climate change, adaptation and mitigation

- Group work to develop a common vision for local development based on current capacities and options to address potential climatic disturbances and other threats

Group work was distributed among three groups, each working on one of the following topics:

- Organisations and regulations to improve the enforcement of activities that consider possible climate disturbances

- Strategies compatible with sustainable management of forests and that address possible climate disturbances

- Capacities needed to improve the social structures that could enhance local development and adaptive capacity 


\section{Local perceptions of change}

Villagers from Mboy II, Mang and Mendoungue have seen important changes since the villages' creation, both in ecological and social terms. They indicated, for example, that agriculture area has expanded over time. In the 1970s, villagers used only a small part of their land for agriculture. Back then production was mainly allocated to subsistence. During that period, the cultivated area was less than 1 ha per household and few farmers produced coffee. The expansion of agriculture started in the 1990s with the introduction of cacao in the region and rising market prices for this product. Since 2000, the expansion of agriculture accelerated even more, mainly due to population growth. Currently, more than half of the local population considers agriculture as the main activity of the household. ${ }^{3}$ Figure 6 illustrates how villagers from Mboy II and Mang perceive trends in the agriculture area since 1970 (change represented in percentages). In both cases, villagers argued that agriculture would continue expanding over the next decade.

Villagers mentioned population growth as the main reason for agriculture land expansion, particularly after 2000. This is reflected in Figure 6, which shows a positive relation between population growth and agriculture area in Mboy II and Mang. According to the villagers, population growth accelerated in the 2000s mainly due to migration into the villages, polygamy and a decrease in child mortality (thanks to the introduction of vaccinations against measles, tuberculosis and tetanus) and better health facilities in general. Participants indicated the population would continue growing in the years to come due to rapid development in the East of Cameroon promoted by local elites and the local government.

Another important change observed by villagers in Mboy II, Mang and Mendoungue over the past decades is a decrease in forest cover and in the availability of NTFPs. Figure 7 shows trends since the 1970s as perceived by groups of men and women in these villages. In all cases, villagers witnessed deforestation of both primary and secondary forests; less availability of bushmeat and fish; and more difficulty in finding NTFPs.

3 Survey results from Mboy II, Djalobekoue and Nampella, June 2011.
Similar to Figure 6, Figure 7 seems to show a negative correlation between population growth in the villages and forest area, and the availability of bushmeat. According to villagers, deforestation started when forest concessions arrived between the 1970s and 1980s. Since 1980, deforestation has continued due to an expansion in the agriculture area driven mainly by population growth, competition for natural resources and low agricultural production. This has been recently exacerbated by the immigration of a large number of paid workers who came to work in the forest concessions in the 1990s. Table 5 below shows the rhythm of deforestation as perceived by surveyed households in Djalobekoe, Mboy II and Nampella.

More than half of the surveyed households stated that deforestation was slow before 1990 but has accelerated since then. Before 1990, according to respondents, there were few forest concessions and fewer plantations. Between 1990 and 2000, the number of forest concessions, mainly of European and Asian origin, multiplied; the combination of weak institutional arrangements, corruption and the recent reformulation of Forest Law No 94 resulted in non-sustainable exploitation practices (including logging and hunting) and negative impacts on the forests.

According to respondents, the main drivers accelerating deforestation since 2000 have been population increase, over-exploitation of forest resources by FMUs and new mining concessions. About half of the surveyed households in Mboy II stated that population growth is the main reason for the accelerated rhythm of forest destruction since 2000. In Nampella and Djalobekoe, half of respondents in each village indicated that accelerated deforestation was mainly due to exploitation practices by forest concessions and establishment of new mining concessions in the area. About 30\% in each of these two villages also identified population increase and competition for agricultural land as important deforestation drivers since 2000.

Furthermore, villagers mentioned wildlife and NTFPs have declined over time. This could be considered a symptom of forest degradation, over-hunting and fauna migration due to human-induced disturbance. Villagers claim that, in 


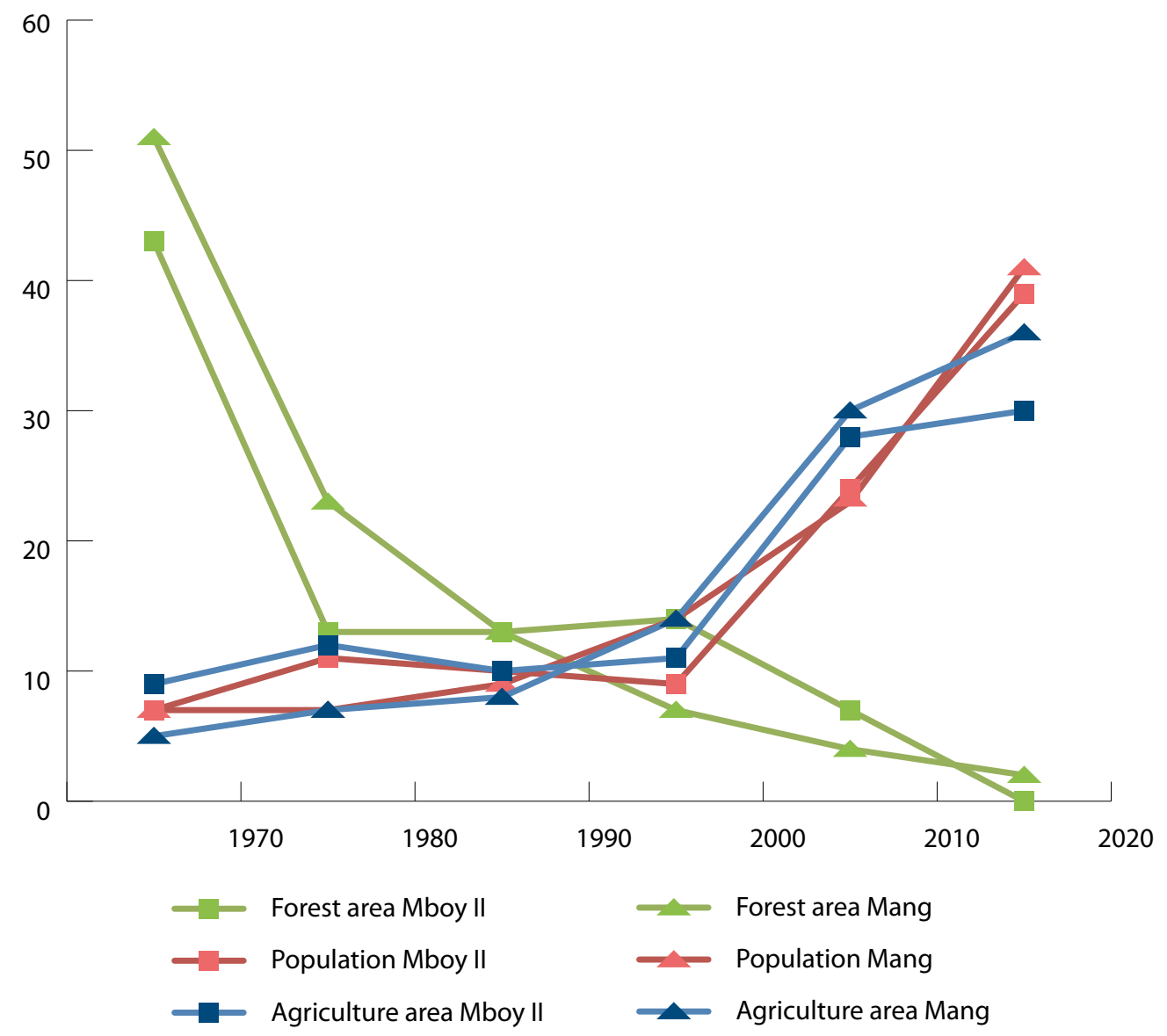

Figure 6. Trends in agriculture area in Mboy II and Mang since 1970

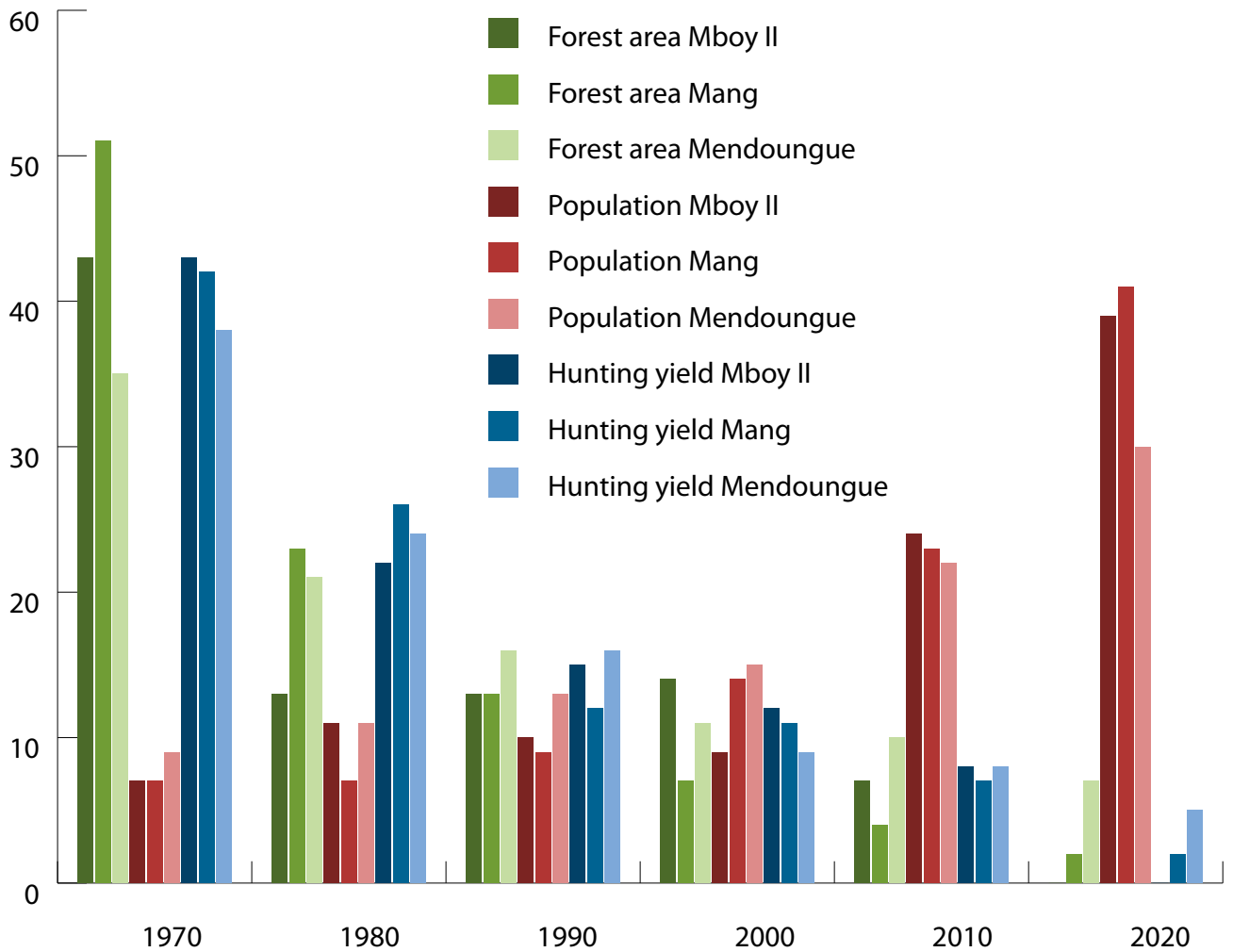

Figure 7. Perceived trends in forest resources since 1970 
Table 5. Rhythm of deforestation before 1990, between 1990 and 2000 and after 2000

\begin{tabular}{llccc}
\hline Rhythm of deforestation & Village & Djalobekoe & Mboy II & Nampella \\
\hline Before 1990 & \% Responses & 87.8 & 69.6 & 85.7 \\
& \% No response & 12.2 & 30.4 & 14.3 \\
& \% Slow & 55.8 & 65.6 & 86.1 \\
& \% Fast & 44.2 & 34.4 & 13.9 \\
\hline 1990 to 2000 & \% Responses & 92.8 & 69.6 & 85.7 \\
& \% No response & 8.2 & 30.4 & 14.3 \\
& \% Slow & 31.1 & 37.5 & 44.4 \\
\hline After 2000 & \% Fast & 68.8 & 62.5 & 55.6 \\
& \% Responses & 89.8 & 73.9 & 85.7 \\
& \% No response & 10.2 & 26.1 & 14.3 \\
& \% Slow & 25 & 20.6 & 13.9 \\
& \% Fast & 75 & 79.4 & 86.1 \\
\hline
\end{tabular}

the 1970s, primary forest surrounded the villages; now villagers must walk at least $5 \mathrm{~km}$ to access primary forest for hunting and collection of NTFPs. For some NTFPs, particularly ones that have been harvested for over three decades like wild mango, walking distances are even longer - from $15 \mathrm{~km}$ to $30 \mathrm{~km}$ (about two walking days). Hunting has also become more competitive and time consuming. According to village hunters, it was possible to catch around 10 wild animals during one day in the 1970s. Currently, hunters leave for two days and catch about five wild animals during the trip. Fish catch from rivers is similar. Villagers believe over-hunting and over-fishing are the main reasons for this decline; these, in turn, are related to human population growth and non-sustainable extractive practices, mainly by forest concession workers and new groups settling in the area.

If current trends continue, particularly if human population growth continues, villagers forecast that forests will become even more fragmented and degraded. They believe people in future will not only migrate to the region for its forest resources, but also for emerging mining opportunities. If this is the case, increased competition will make hunting and collection of NTFPs even more difficult. Walks to find these resources will take longer and some will probably require a form of domestication to become more accessible. Most of the surveyed households indicated that forests risk disappearing in the future, as they would be converted into different land-use types. Figure 8 shows the words that appeared more frequently when households were asked to make predictions about forests for the next 10 years.

In addition to trends, villagers identified several disturbances or threats that affected the villages in past decades. These disturbances are of a different nature, including changes related to society, ecology, economics and technology. It is important to note that disturbances can occur as discrete events in time, referred to as a shock or perturbation to the system, or can be gradual, which is then recognised as a stress

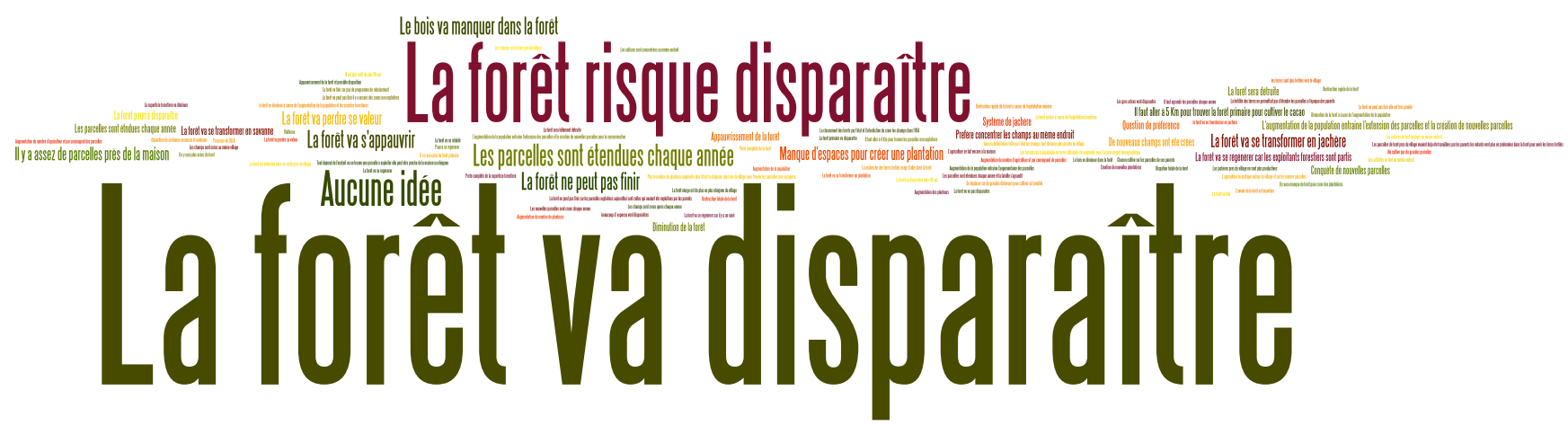

Figure 8. Perceptions about the future of forests in Mboy II, Djalobekoe and Nampella

Note: Larger words reflect words that appeared more frequently in the narrative responses. 
or pressure on the system (RA 2010). A disturbance or threat is generally but not always external to the case of analysis; it can also be part of natural fluctuations that relate to the natural variability of the system. In MBoy II, Mang, Djalobekoe and Mendoungue, village representatives identified threats from the 1970s to the present. Table 6 shows the chronological list of perceived threats and major events in two of the villages, namely MBoy II and Mang.

Although this is not a comprehensive list of all the past changes that may have affected the villages, it provides a useful overview of the multiple stresses and shocks that influenced them. Some threats identified by the villagers relate to stresses (i.e. gradual changes) such as a shift in the seasons and scarcity of water resources, while others relate to shocks (i.e. abrupt or discrete events) such as diseases, pest invasions and intense droughts. Some implications of these events, as explained by villagers, were life loss (e.g. increase in infant mortality due to measles and diarrhea epidemics), increase in revenues (e.g. due to growth in the coffee market and mining activities) and decreases in production and income (e.g. due to pest invasions, drought, shift in the seasons and water scarcity).
Among several threats identified by villagers in Mboy II, Mang and Djalobekoe, only some depend directly on climate variables, such as changes in mean temperature and total rainfall. Table 7 provides a summary of climate-related disturbances as perceived by villagers.

Some climate-related disturbances only happened once in the memory of the villagers (i.e. intense and prolonged drought during five months and caterpillar invasion during one season). Other events (i.e. violent winds, shifts in the seasons, drying water sources and diarrhea) have developed gradually and become more notorious and frequent since the 2000s. For instance, villagers in Djalobekoe mentioned that strong winds used to appear only during the long dry season, but have become more frequent and tend to affect the village during the short rainy season as well. These gradual events are probably also related to each other. For example, villagers mentioned that changes in the seasons (e.g. longer dry season, sporadic rain) decrease the availability of water sources; this forces the population to use polluted river water, which is causing diarrhea.

Table 6. Historical trendline of major events and threats

\begin{tabular}{|c|c|}
\hline Year & Major events of threats \\
\hline 1970 s & Growing coffee market \\
\hline 1982 & Intense and prolonged drought of 5 months (Mboy II, Mang) \\
\hline \multirow[t]{2}{*}{1985} & Measles epidemic (Mboy II, Mang) \\
\hline & Forest fires (Mboy II) \\
\hline $1987-1988$ & Creation of new churches (Mang) \\
\hline 1990 & Pest (caterpillar) invasion and destruction of cacao plantations and gardens (Mang) \\
\hline 1990 onwards & Migration from Central African Republic and other regions of Cameroon (Mboy II) \\
\hline 1992 & Transition to multiple political parties (Mboy II) \\
\hline 2000 onwards & Shift in seasons (Mboy II) \\
\hline 2000 & Construction of Baka school by the Swiss (Mang) \\
\hline \multirow[t]{2}{*}{2001} & Scarcity of water due to change in seasons (Mang) \\
\hline & Diarrhea epidemic (Mang) \\
\hline \multirow[t]{2}{*}{2004} & Arrival of mining companies (Mboy II) \\
\hline & Swine flu (Mang) \\
\hline 2005 & Baka population affected by 'du pian' (a skin condition) (Mboy II) \\
\hline 2006 & 3000 cattle from Central African Republic escaping the war in the country (Mboy II) \\
\hline 2007 onwards & Shift in the seasons and strong winds (Mang) \\
\hline 2010 & Spread of conjunctivitis (Mboy II) \\
\hline
\end{tabular}


Table 7. Description of climate-related disturbances

\begin{tabular}{|c|c|c|c|}
\hline $\begin{array}{l}\text { Climate-related } \\
\text { disturbances }\end{array}$ & $\begin{array}{l}\text { Shock } \\
\text { or stress }\end{array}$ & $\begin{array}{l}\text { Increase in } \\
\text { frequency }\end{array}$ & Magnitude \\
\hline Drought & Shock & No & High \\
\hline $\begin{array}{l}\text { Caterpillar } \\
\text { invasion }\end{array}$ & Shock & No & Medium \\
\hline $\begin{array}{l}\text { Drying water } \\
\text { sources }\end{array}$ & Stress & $\begin{array}{l}\text { Yes since } \\
2000\end{array}$ & Medium \\
\hline $\begin{array}{l}\text { Diarrhea } \\
\text { epidemic }\end{array}$ & Stress & $\begin{array}{l}\text { Yes since } \\
2000\end{array}$ & High \\
\hline $\begin{array}{l}\text { Shifts in the } \\
\text { seasons }\end{array}$ & Stress & $\begin{array}{l}\text { Yes since } \\
2000\end{array}$ & High \\
\hline Strong winds & Stress & $\begin{array}{l}\text { Yes } \\
\text { recently }\end{array}$ & Medium \\
\hline
\end{tabular}

Results obtained from the surveys in the villages of Mboy II, Nampella and Djalobekoe corroborate results from focus group discussions, particularly in relation to shifts in the seasons and extremes related to climatic variability (see Figure 9). Among the main climate-related disturbances specified by the surveyed households are: prolonged dry season $(54 \%$ of responses for the category), prolonged wet season (46\%), strong winds (46\%), dry spells in wet seasons (42\%) and intense rain (27\%). These disturbances seem to be felt relatively equally in all surveyed villages as illustrated in Figure 9.

Changes or shifts in the seasons seem to be the main climate-related disturbance affecting the villages. According to villagers, changes in the seasons have been felt for the past 10 years. Villagers in Mboy II and Djalobekoe explain:

\footnotetext{
'In the past, seasons were easy to differentiate: the long dry season would span from mid November to mid March, the short rain season would take place from mid March to mid June, the short dry season would then start from mid June to mid August, followed by the long rain season from mid August to mid November'.
}

The description of seasons above can be compared to trend records collected in the Ouesso meteorological station located $250 \mathrm{~km}$ southeast from Yokadouma in Ouesso, Sangha, Congo. This location shares similar characteristics to Yokadouma. Figure 10 shows the observed monthly rainfall totals for the period $1979-2000$. The graph shows bimodal seasonality, which corresponds to villager descriptions. The graph also shows a high inter-annual variability, particularly in the months of May, September and October, which seem to be peak wet months.

According to villagers, rain has become more erratic since the early 2000s, making it more difficult to predict. Over the past decade, villagers have observed that:

- It rains regularly during the long dry season (mid November to mid March)

- The short rain season (mid March to mid June) starts earlier, in February

- The short rain season is 'divided' by a period of dryness in April, after rains have started. Rain returns in May and continues until late June, prolonging the short rain season

- The long rain season (mid August to mid November) has shortened and rain is more intense during this season

- The short dry season (mid June to mid August) tends to shorten, or even disappear in some years, as it rains regularly during this season

Unfortunately, due to limited access to station data, public perceptions cannot be compared to observed station records for the post-2000 period. However, observed climate can be reproduced at the station scale; a downscaling method could use a climate re-analysis circulation dataset such as NCEP (see Maraun 2010 for an updated review of statistical downscaling). The resulting downscaled time series can be used to analyse the 1979-2009 period for the Ouesso station. It is important to bear in mind, however, that re-analyses tend to have slightly reduced variance; real changes might be somewhat moderated and it is more difficult to trace rainfall variability (Jack, C. personal communication). Also, the re-analysis fails to reproduce bimodal seasonality. Therefore, these projections (and monthly data series in general) should be considered carefully when assessing seasonal shifts.

Monthly total rainfall time series for December, January and February during the NCEP re-analysis period of 1979-2009 (Figure 11) show more rainfall in the dry season, as perceived by stakeholders. Figure 12 shows rain days rather than total rainfall and focuses on rainy days in February because this seems to be the month that demonstrates most changes since 2000 . The re-analysis suggests the changes noted in the long dry season are happening at the end of this season. Probably this also explains why participants perceive the short wet season is starting earlier. 


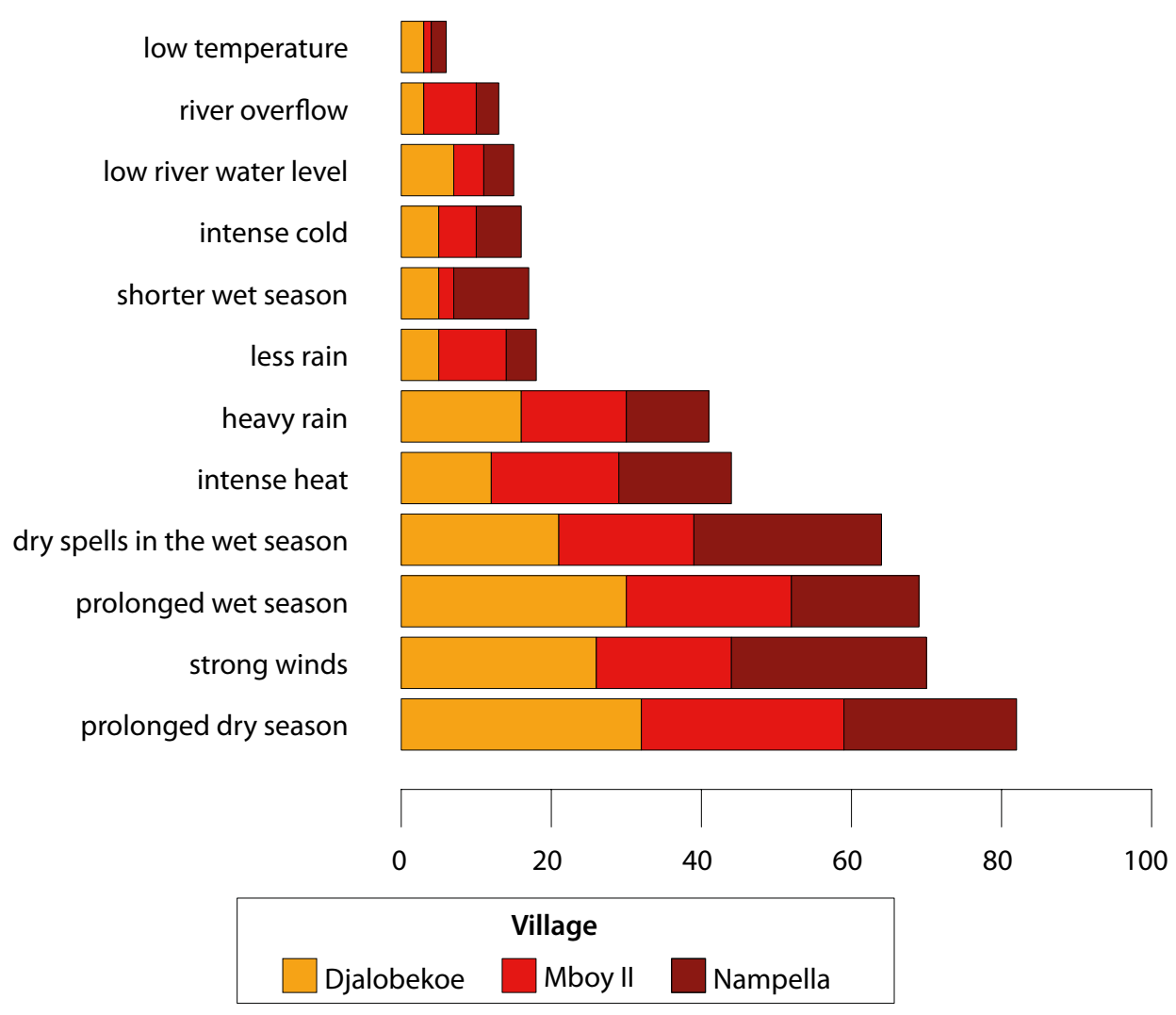

Figure 9. Climatic disturbances specified by surveyed households

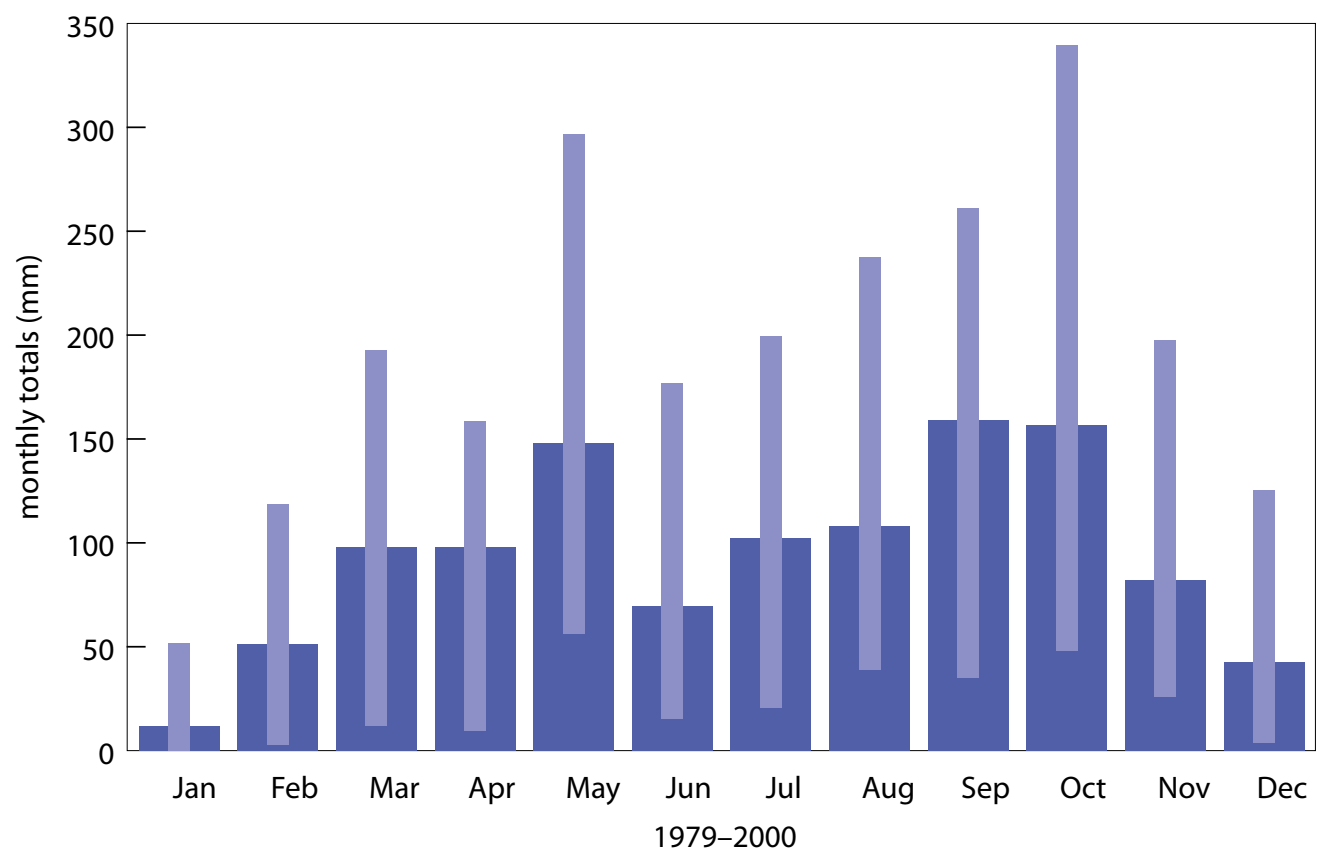

Figure 10. Observed monthly rainfall totals

Note: Observed monthly rainfall totals climatology (wide bars) with $10^{\text {th }}$ to $90^{\text {th }}$ percentile inter-annual range (narrow bars), Ouesso station coordinates: $1.62^{\circ} \mathrm{N}, 16.05^{\circ} \mathrm{E}$, altitude: 352 metres Source: Climate Information Portal, Climate Systems Analysis Group (2011) 
A decrease in total rainfall since 2000 during the month of April could also be inferred from plotting the NCEP re-analysis data from 2000 to 2007

(Figure 13). This trend is in line with the perception of 'dryness' in April indicated by participants. Plotting rainfall or rain days for the rest of the months in both stations does not give enough information to draw a reliable analysis.
Perceived changes described above have disturbed the villages in several ways. The next section will explain how these threats affect diverse groups and activities in the villages, considering their differential exposure and their dynamic vulnerability to climate-related threats.

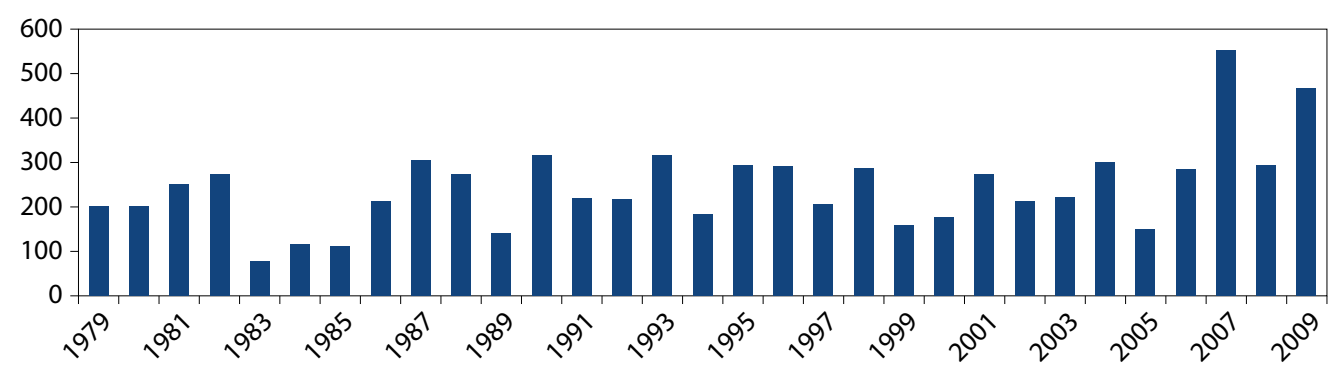

Figure 11. Total rainfall for the December-January-February period using 1979-2009 NCEP re-analysis data, Ouesso station

Source: Climate Information Portal (2011)

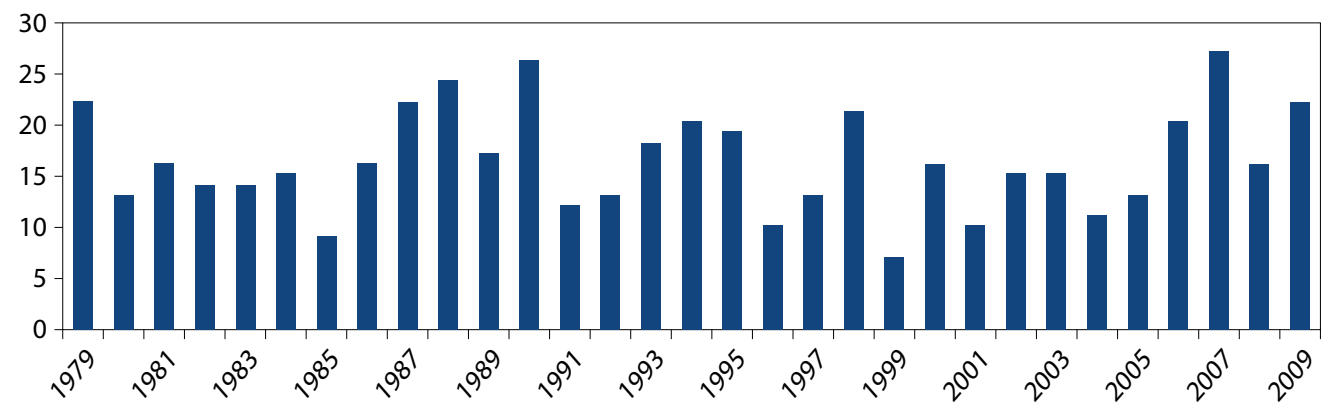

Figure 12. Rain days for February using 1979-2009 NCEP re-analysis data, Ouesso station Source: Climate Information Portal (2011)

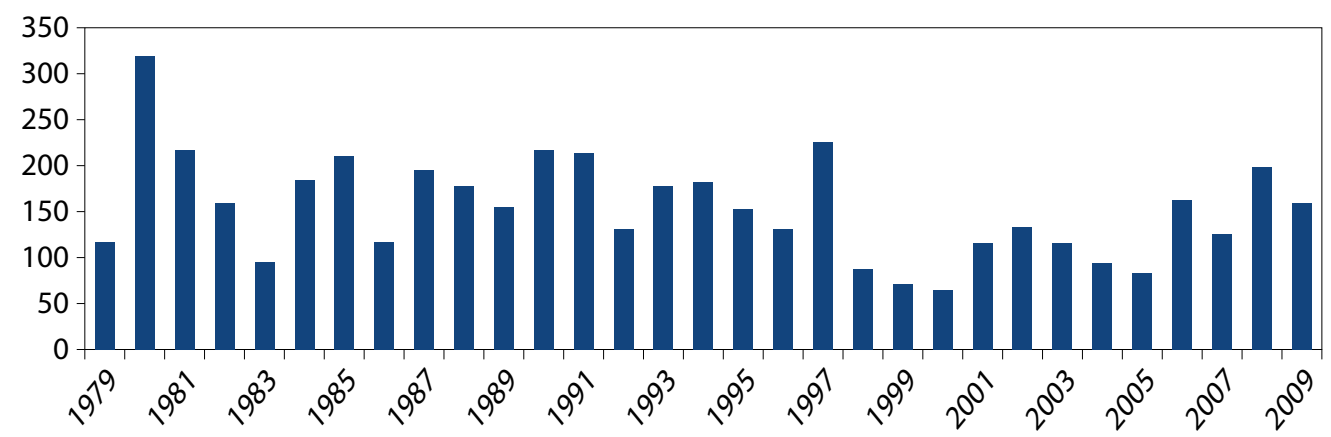

Figure 13. Total rainfall for April using 1979-2009 NCEP re-analysis data, Ouesso station Source: Climate Information Portal (2011) 


\section{Dynamic vulnerability and differentiated exposure}

Vulnerability is a dynamic process, changing on a variety of inter-linked temporal and spatial scales. On the one hand, it is bound by processes of change that can be slow or abrupt and unexpected in nature. On the other, it results from the actions and multiple attributes of human actors, and the functioning of multiple ecosystems interacting at different scales. To understand better the current vulnerability of the villages on the Cameroonian side of the TNS Landscape, this section focuses on four key attributes that shape the vulnerability of diverse groups and activities in the villages:

1. production system: to understand the different effects of climate-related disturbances;

2. role of forests: to understand the use and benefits villagers obtain from them, and possible implications of climate-related threats in this process;

3. livelihood diversification and trade: to understand the multiple subsistence and income-generation activities in the village, dependence on both external capital flows and market price fluctuations, and safety nets in times of stress;
4. social capital and collective action: to analyse the ability of villagers to act collectively to address common problems and manage common resources for the benefit of villages.

Inherent to dynamic vulnerability is the understanding that different social groups or economic activities, ecosystems or specific natural resources are exposed to threats in different ways. Vulnerability, and hence expected impacts, are unlikely to be the same for all villagers, even considering the ensemble of climate-related threats identified in the previous section (drought, climate-related diseases, drying water sources, shifting seasons and winds).

To capture differentiated vulnerability, villagers discussed how these threats affected different 'exposure units' in the past. 'Exposure units' are activities, resources or social groups that are considered important for the village and exposed to threats. In this particular analysis, villagers defined the exposure units. Table 8 shows how villagers from Mboy II, Mang and Djalobekoe described the effect of climate-related threats on different exposure units.

Table 8. Vulnerability matrix

\begin{tabular}{llcccc}
\hline & Exposure unit & Intense drought & $\begin{array}{c}\text { Changing } \\
\text { seasons }\end{array}$ & Pest invasion & Strong winds \\
\hline Social Group & Children & -3 & -1 & -1 & - \\
& Elderly & -3 & -1 & -1 & - \\
& Women & -2 & -1 & -1 & - \\
& Men & -2 & -1 & -1 & -3 \\
\hline Activity/ & Agriculture & -3 & -3 & -3 & - \\
livelihood & Hunting & - & +3 & - & - \\
& Fishing & - & -2 & - & - \\
& Breeding & - & +2 & - & -1 \\
\hline Natural resource/ & Forest & -3 & - & - & -3 \\
ecosystem & Gardens & -3 & -3 & -3 & -1 \\
& Cacao & -3 & -3 & -3 & -2 \\
& NTFP & -2 & -1 & -2 & -2 \\
& Manioc & -2 & +3 & - & -3 \\
\hline
\end{tabular}

Note: Level of magnitude or potential impact can range from ' 1 '=low to ' 3 '=high; potential impact can be either ' + '= positive or ${ }^{\prime}{ }^{\prime}=$ negative. 
The scales and signs used are qualitative, but help provide an idea of the magnitude of the threat should it become an impact (i.e. the effect) and the type of this potential impact (i.e. positive or negative). It is not possible to use values in Table 8 as absolute numbers to add them up: they only indicate the perception of different village groups, and exposure units were not always consistent among all the villages. Instead, values in Table 8 provide an idea of climate-related threats that appear to represent a high potential impact and the exposure units that appear to be most vulnerable.

Among the threats listed above, droughts and changing seasons seem to represent the highest potential impact for the villages. The intense drought experienced by participants in the early 1980s severely affected agriculture, damaging production of coffee, cacao, manioc and the gardens. In addition to agriculture, forests were also affected by the severe drought as it caused fire outbreaks that villagers were not used to dealing with. Forest fires also damaged cacao plantations, as these are often located in the secondary and primary forests.

In terms of social groups, drought mainly affected children (who were more prone to diseases such as diarrhea and measles) and the elderly (who could not go out during hours of high heat). In Mang, participants mentioned the measles epidemic that followed the 1982 drought killed around 400 children in the area over two months. While this intense drought was an isolated event, villagers continue to face periods of dryness, particularly since 2000. During these periods, water sources dry out and villagers are forced to use river water, which results in diarrhea epidemics among the population, particularly children. In addition, changes in the seasons since 2000 seem to be an important factor with negative as well as positive impacts, depending on the exposure unit.

Clearly, vulnerability cannot be considered as an aggregate, but needs to be explored from different angles to understand the nuances of differential exposure. The following sections deepen this analysis further by considering attributes that shape vulnerability in the villages over space and time.

\subsection{Production System}

The production areas are located in the village area and the Community Forests. In general, agriculture production fields are located near the villages.
Gardens with vegetables, manioc, plantain and corn, as well as coffee plantations - the oldest among the production fields - extend close to houses along the rivers and in the secondary forest. When villages expand, they generally encroach upon these fields. Cash crop production fields such as cacao plantations lie around 2 to $5 \mathrm{~km}$ from the villages; they are located in secondary and primary forests to benefit from the shadow of large trees that have been left standing.

According to village farmers, changes in the seasons are affecting the production calendar, which used to be clearly defined but now needs to be adapted to erratic rainfall patterns. Figure 14 illustrates the production calendar and the activities that are mainly conducted by men and women as described by the villagers of Mboy II. Most agriculture activities take place in the first half of the year, which covers the end of the long dry season, the short rain season and the short dry season. This coincides with the time of the year when villagers perceived most of the changes in the seasons, as well as changes identified in the NCEP re-analyses using downscaled climate data (see previous section). The NCEP re-analyses data do not confirm all local perceptions and do not simulate well the bimodal seasonality. However, they show more rainfall during the long dry period, particularly at the end in February, and less rainfall during the short rainy season. Agricultural activities in the villages are, therefore, more exposed to changes in seasons and increased climate variability.

According to villagers in focus groups, changes in the seasons mainly affect agriculture. While some products have benefited from changes in weather patterns, such as plantain and manioc, villagers perceive most of the impacts on agriculture as negative. Not being able to cope with erratic rainfall patterns has resulted in problems with pests and weeds, and has disturbed the production cycle of important crops. Rains during the short dry season have led to phytosanitary problems and proliferation of weeds; lack of rain and pockets of dryness in the short rain season have resulted in falling flowers and loss of seedlings. As a consequence, there is reduced production quantity and quality. In addition, villagers noted the second production cycle has become more difficult because it rains during the short dry season and plants in the field do not dry properly. Burning in this period has also become more complicated and it is difficult to know when to prepare the land for seeding. 


\begin{tabular}{|c|c|c|c|c|c|c|c|c|c|c|c|c|c|c|}
\hline \multicolumn{15}{|c|}{ MONTHS } \\
\hline \multirow{2}{*}{\multicolumn{2}{|c|}{$\begin{array}{l}\text { Perceived } \\
\text { changes }\end{array}$}} & \multicolumn{6}{|c|}{ Short wet season starts earlier } & \multicolumn{7}{|c|}{ Long wet se ason is shorter and with intense rains } \\
\hline & & \multicolumn{7}{|c|}{ Dry spells in April } & \multicolumn{5}{|c|}{ Rains during dry season } & Rains \\
\hline M & $\mathrm{F}$ & ACTIVITIES & Jan & Feb & Mar & Apr & May & Jun & Jul & Aug & Sept & Oct & Nov & Dec \\
\hline$x x$ & $x$ & Clearing & & & & & & & & & & & & \\
\hline$x x$ & $\mathrm{x}$ & Felling & & & & & & & & & & & & \\
\hline $\mathrm{x}$ & $\mathrm{x}$ & Burning & & & & & & & & & & & & \\
\hline $\mathrm{x}$ & $\mathrm{x}$ & Cleaning & & & & & & & & & & & & \\
\hline $\mathrm{x}$ & $x x$ & Seeding & & & & & & & & & & & & \\
\hline$x$ & $x x$ & Weeding 1 & & & & & & & & & & & & \\
\hline $\mathrm{x}$ & $x x$ & Weeding 2 & & & & & & & & & & & & \\
\hline & $x x$ & Harvesting & & & & & & & & & & & & \\
\hline $\mathrm{x}$ & $x x$ & Drying & & & & & & & & & & & & \\
\hline $\mathrm{x}$ & $x \mathrm{x}$ & $\begin{array}{l}\text { Collecting } \\
\text { NTFPs }\end{array}$ & & & & & & & & & & & & \\
\hline $\mathrm{x}$ & $\mathrm{x}$ & Fishing & & & & & & & & & & & & \\
\hline$x x$ & & Hunting & & & & & & & & & & & & \\
\hline
\end{tabular}

Figure 14. Production calendar

Results obtained from surveys confirm the focus group discussions on the effects of season shifts and increased climate variability on agriculture. Almost three quarters of the survey responses $(73 \%)$ indicated decreased agricultural production as one of the main perceived impacts of climate-related disturbances. Other important perceived impacts related to agriculture are decreased income from agricultural production $(50 \%)$ and problems with storage and drying of products (38\%).

\subsection{Role of forests}

While secondary forests are located close to the villages, primary forests are more spread out and often located between communal areas and FMUs. Primary forests are used for hunting, fishing, cash crop plantations and collection of NTFPs. Secondary forests are used for garden agriculture, coffee and cash crop plantations.

Villagers consider the forestland as 'territory that belongs to the ancestors', a collective property owned by past, present and future generations. Most households have only access to a specific part of the forest. In Mboy II, only 17\% of surveyed households had access to all the forest in the village land; in Djalobekoe almost 40\% had access; and in Nampella about $29 \%$ had access. Households with access to all forestland seem to belong to families that first settled the villages; they could claim use of all the forest based on the right of 'discovery of unoccupied land', which applies in the villages. New migrants, on the other hand, have to ask permission to the entity managing the forestland if they want to access NTFPs. For example, if the NFTP will be collected from the village forestland, the newcomer needs to receive authorization from the village chief and his notables; if a clan controls the land, the newcomer must request permission from the head of the clan. In general, village chiefs validate an arrangement already negotiated between the newcomer and a head of household or management entity.

Distribution of forestland is often a source of conflict in the villages. Establishment of FMUs was the main reason for limited access to forests, with more than $50 \%$ of surveyed households indicating this as a factor. Other factors comprised establishment of reserves, land distribution between families, establishment of plantations, mining activities and land set aside for hunting or safari activities.

Forests play a key role in the system, providing villagers with resources and services for their subsistence and economic activities. They also represent an important safety net, as villagers use timber and NTFPs to diversify their economy and livelihood base (see next section). According to villagers, several activities depend on primary and 


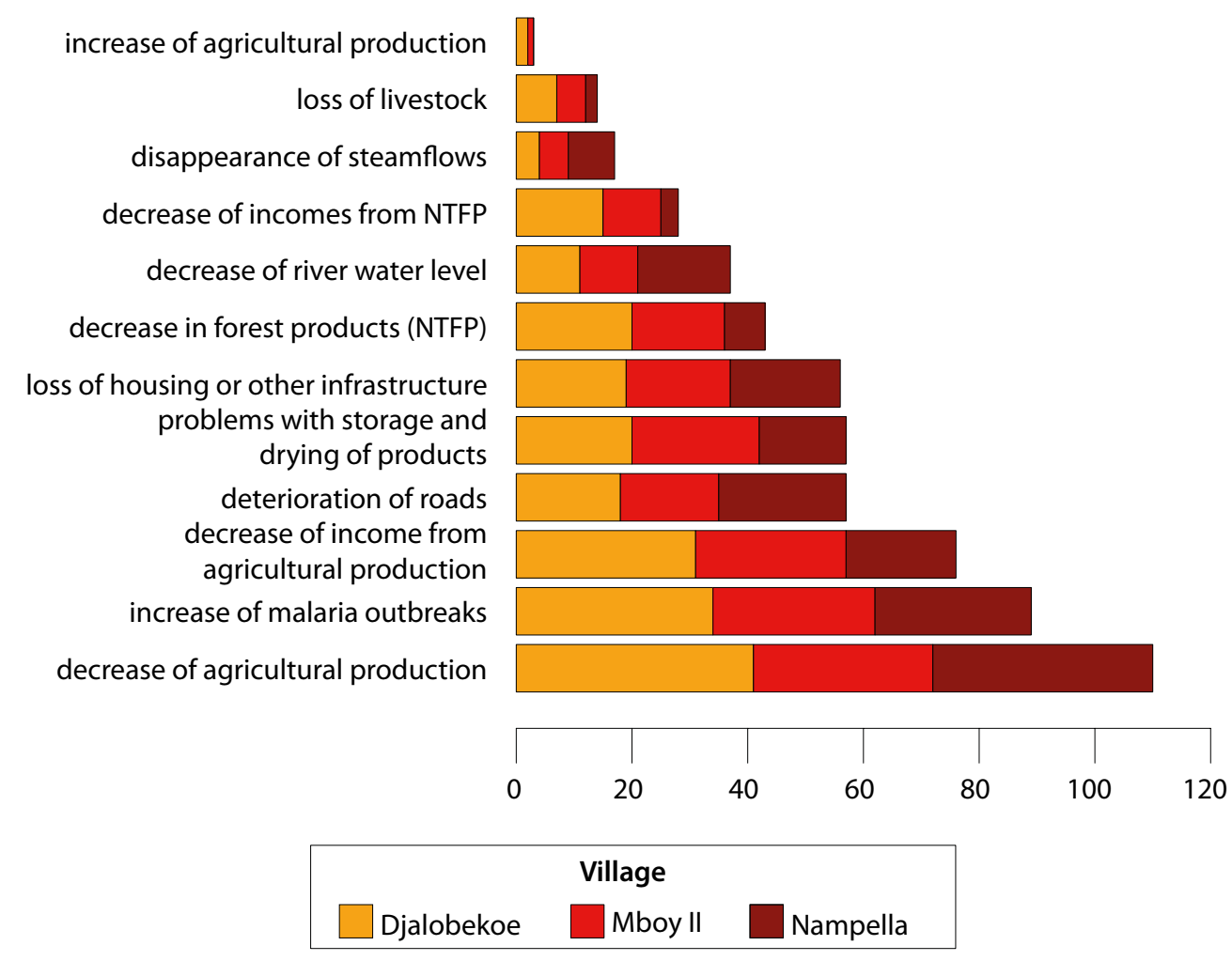

Figure 15. Effects from climate-related disturbances specified in the survey

secondary forests, such as hunting, collection of NTFPs, fishing, timber harvesting, water harvesting, construction and health care. Figure 16 illustrates how men and women groups in Mboy II use forest resources to fulfill their needs.

Forest resources are mainly used for nutrition and income generation, but also for other subsistence activities. For example, women emphasised that several forest resources can be used for medicinal purposes (e.g. for stomach problems among children), and men added uses such as construction of housing and social infrastructure, as well as physical protection against strong winds and storms. When villagers were asked to consider the forest as a whole (i.e. as one ecosystem), they indicated a series of perceived benefits as illustrated in Figure 17. Both men and women shared similar views. While most of these benefits were already captured when discussing specific forest resources, cultural rituals attached to forests seem to be more evident only when considering the forest as a whole.

Although not all NTFPs seem to be close and easy to access, many remain abundant and can still be found in village forests. In some instances, harvest of some NTFPs has only started recently; these can still be found close to the villages. For example, villagers of Mboy II mentioned they have only traded NTFPs since 2009, and only collected and processed Djanssang since 2010. Table 9 describes the abundance and seasonality of the main NTFPs as perceived by the locals in Mboy II, Mang and Mendoungue. According to the villagers, these NTFPs are easy to sell in the market, but their trade is still highly informal and not well organised.

In general, according to participants, forests seem to be less affected by changing seasons because of their diversity and resilience to this variability. Although NTFPs are seasonal, villagers state NTFPs have not been seriously affected by recent changes in the seasons, with the exception of mushrooms. On the contrary, rain during the short dry season seems to have benefited some of the NTFPs; this supports the livelihood base of farmers because more wild plants are available for collection. More wild plants during the small dry season have also benefited domestic and wild animals, which use them as food.

\subsection{Livelihood diversification and trade}

The livelihood and economic base of the villages relies on several subsistence and commercial activities such as agriculture, animal breeding, hunting, fishing and collection of NTFPs. Garden products, fish 


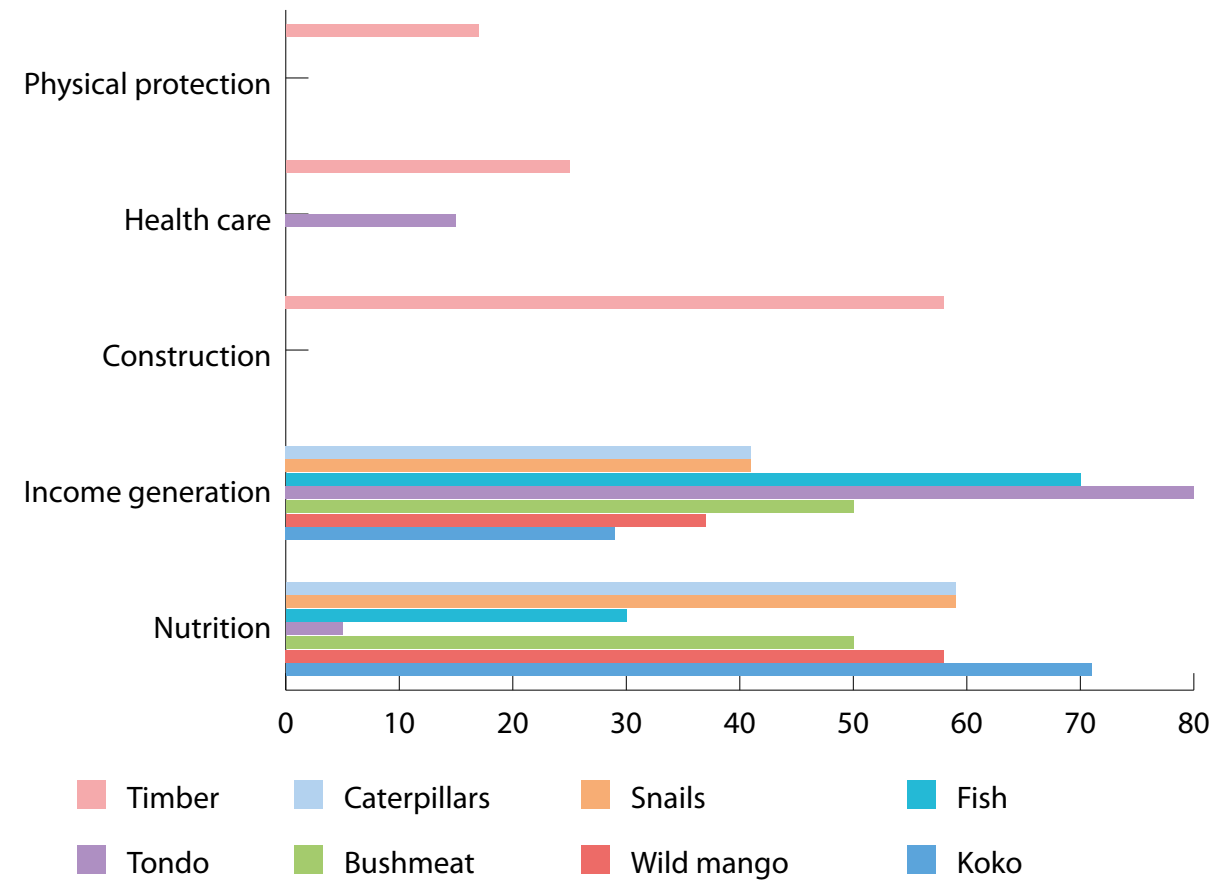

Figure 16a. Use and benefits from forest resources in Mboy II (men)

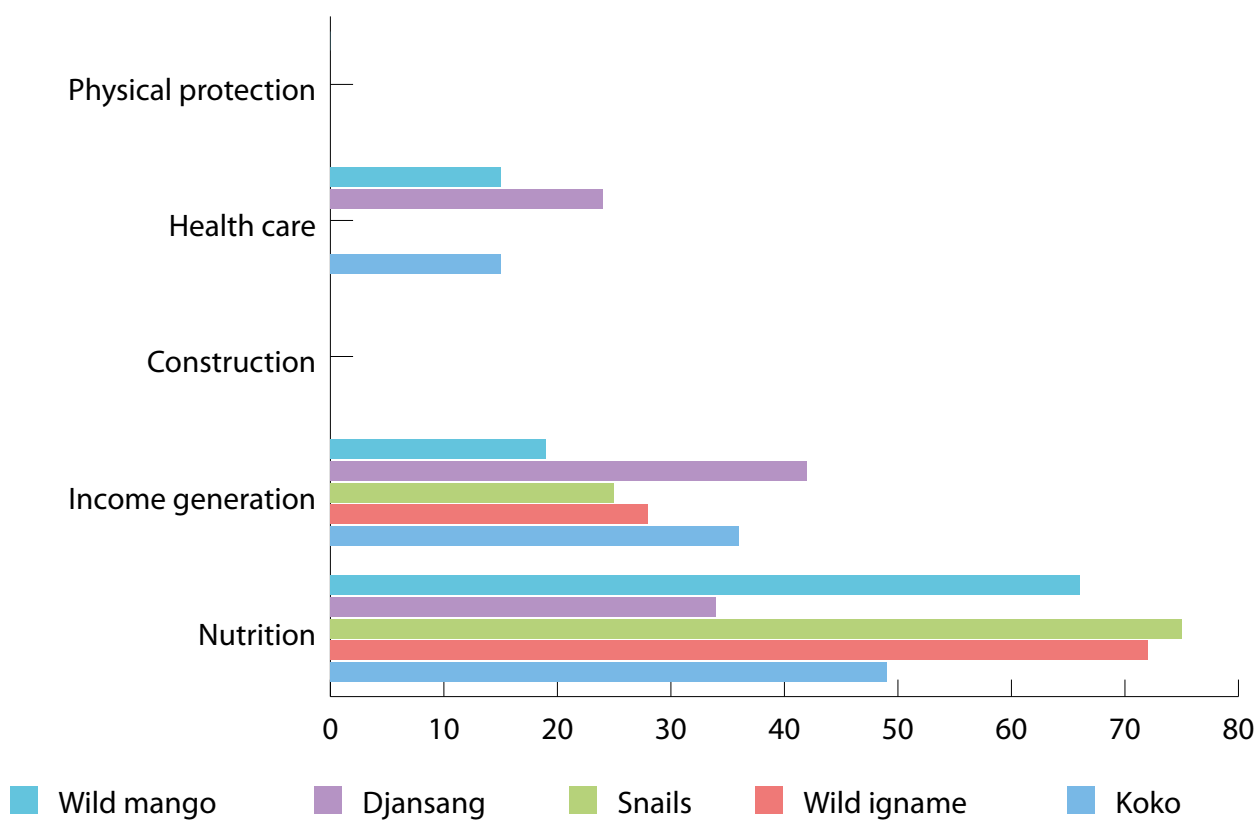

Figure 16b. Use and benefits from forest resources in Mboy II (women)

and bushmeat generated from these activities are mainly used for subsistence, while products such as cacao, pepper, coffee and some NTFPs are traded for revenue generation. Some villagers also work for pay in forest concessions and mining activities. Nonetheless, the majority of the villagers are farmers who base their livelihood on the production of cash crops, garden products and the collection and trade of NTFPs.
Based on surveyed households in Mboy II, Djalobekoe and Nampella, the main activity in the villages is agriculture, followed by collection of NTFPs and hunting. Products that are important source of revenues and generate the highest income for the households are cacao (mean $560500 \mathrm{cfa}$ ), followed by manioc (89520 cfa) and plantain (49 $690 \mathrm{cfa}$ ). Products that generate high income but have been mentioned by fewer households are 


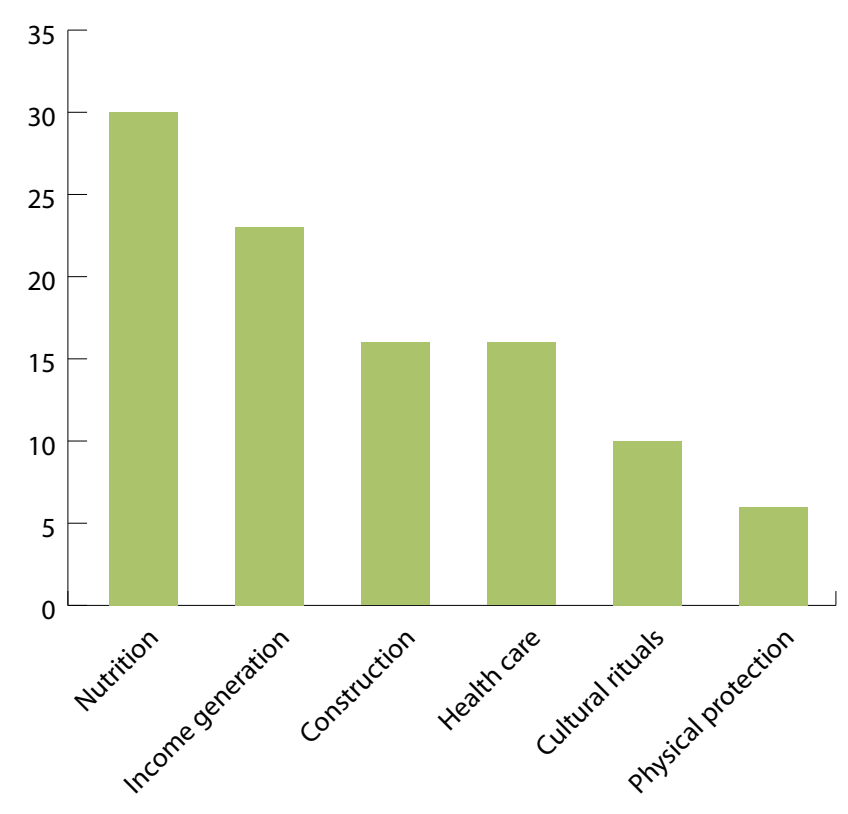

Figure 17. Perceived benefits from forests in Mboy II

Table 9. Abundance and seasonality of main forest resources

\begin{tabular}{lcl}
\hline Forest resource & Abundance & $\begin{array}{l}\text { Seasonality (for } \\
\text { collection) }\end{array}$ \\
\hline Koko & 3 & All year \\
Wild mango & 3 & June-August \\
Djanssang & 2 & August-October \\
Tondo & 1 & October-March \\
Mushrooms & 3 & March-November \\
Fish & 2 & January-November \\
Snails & 2 & July-November \\
Caterpillar & 3 & August-September \\
Bushmeat & 2 & All year \\
\hline
\end{tabular}

Abundance is defined in a participatory way by selecting either $3=$ high, $2=$ medium, or 1=low

coffee (75 $000 \mathrm{cfa})$ and bushmeat (173 $200 \mathrm{cfa})$ (see Figure 18). Corn and fish seem to generate high income but have provoked even fewer responses. Corn provides revenues especially for women, who use it to produce and sell a local alcoholic drink known as Arki. Other sources of revenue such as NTFPs and livestock play a less important role for the economic base of the villages; however, they remain a central part of subsistence activities (see previous section).

The livelihoods and economic base are somewhat different between groups of men and women in the villages.

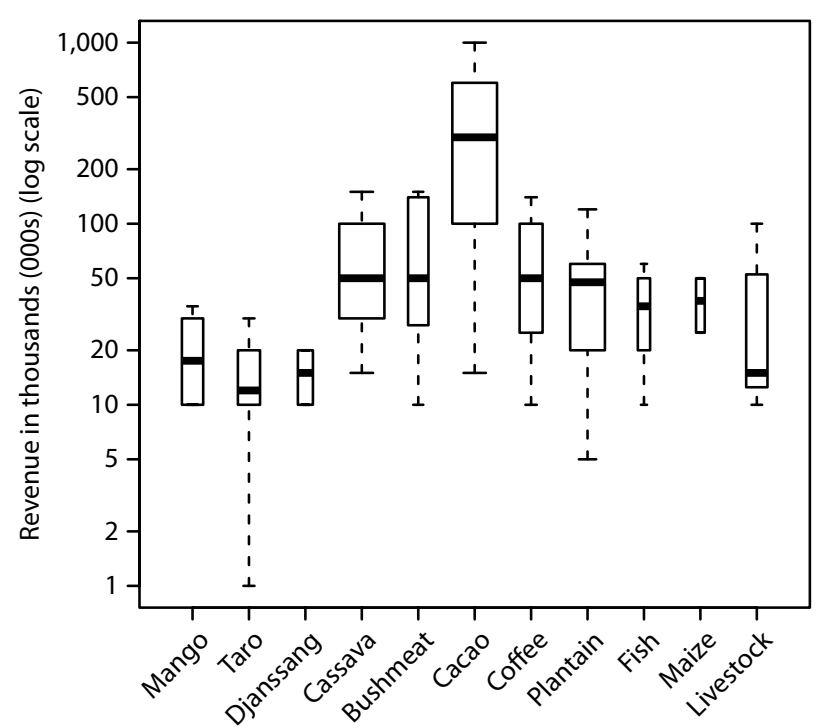

Figure 18. Main sources of revenue in the villages of Mboy II, Djalobekoe and Nampella (Annual revenues in cfa)

Note: Each box shows a product with a median (thick horizontal bar) and the full range of responses (variance). The width of the boxes is relative to the number of responses, which represents the importance of that product as a source of revenue.

For women, the most important products in terms of revenue generation are: garden products or food crops (representing around $25 \%$ of total revenue) like manioc, plantain and corn; cash crops (around 10\%) like coffee, cacao and pepper; NTFPs (15\%) such as Njembe, Djanssang, Mpeke, Igname; and fish (20\%), which includes river shrimp.

Women also indicated that Arki is an important product for income generation. It represents about $25 \%$ of total revenues and can be used as a safety net in case cash crops do not generate enough revenues. Arki has been commercialised legally in Cameroon since 1982. Products that generate higher revenue for women seem to be also products where women invest most of their labour time. This is particularly the case for garden products, as women use them for their subsistence, cash revenues and the production of Arki. In addition, women invest about $10 \%$ of their labour time in collecting NTFPs. Although NTFPs contribute to cash revenue, they are seasonal, knowledge is required to find them and their commercialisation is not well organised. Therefore, more time is given to other activities that seem more cost-effective.

Men, on the other hand, indicated the most important products for them, in terms of revenue generation, are: cash crops (about 30\% of their total revenue) like cacao, coffee and palm oil; garden products (about 30\%) such as manioc, peanut, 
plantain, corn, Igname and macabo; and animal breeding (around 15\%) such as sheep, goat, chicken, pigs, duck and pigeon. Most of the men's labour time is invested in cash crop and garden production, and about 3\% of their time in NTFP collection.

Men and women also have different ways to allocate revenues generated from their economic activities. From discussions with women and men groups in Mboy II, it seems that most revenues generated by women are assigned to education (about 30\%), food and health (15\% and 12\% respectively) and home utensils $(10 \%)$. In the case of men, most revenue is allocated to investment in the production system $(20 \%)$, education $(15 \%)$ and construction $(10 \%)$. Please note these figures do not account for debt payment.

Villagers also allocate revenues from diverse activities in different ways. While revenues from forest resources seem to be mainly used for food and education, agriculture revenues seem to be allocated mainly for health, leisure and debt payment. According to villagers in Mendoungue, forest resources provide a safety net to fulfill household needs. On the other hand, when revenues from agriculture are decent, households allow themselves to spend money on health problems. Nearly half of agriculture revenues are also used to pay debts from micro-credits. To a lesser extent, agriculture revenues are also assigned to cover food, construction, education and clothing.

In terms of trade, all villages have access to markets either in the frontier market with the Central African Republic or in more urban markets in Yokadouma or Bertua. Since the 1950s, many agricultural products have been exported from the villages to other parts of Cameroon. In the 1960s, the villages started to import products such as petrol, clothing and kitchen utensils. Mining products (i.e. diamond, gold) have been exploited around the villages in artisanal ways and sold in other parts of the country since the 1980s. The village has been exporting agricultural products to the Central African Republic since the 1990s, mainly palm oil, plantains, avocados, pine apples, potatoes and sugar cane. Different agricultural products coming from the CAR have also been sold in the village since the 2000s at the new weekly frontier market in Mboy II.

Product prices vary depending upon where products are commercialised. Generally, products traded within the villages or through intermediaries have lower prices than products traded directly in Yokadouma or Bertoua. In general, villagers either trade through intermediaries that collect the product in the village and transport it to Yokadouma or Bertoua, or trade it themselves using small vehicles. However, the road connecting the villages with Yokadouma is not always in good condition to drive small loaded vehicles, particularly during rainy seasons; direct access to urban markets is not always possible for distant villages. Also, although prices are higher in Yokadouma and Bertoua, villagers need to cover transportation costs if selling their own products; this sometimes becomes a barrier and a reason to use intermediaries instead. Nevertheless, villagers mentioned they must travel to these two locations to buy manufactured products for the households. Table 10 shows the different product prices when traded in the markets of Mboy II, Yokadouma and Bertoua.

From discussions with villagers, it seems that price fluctuations in local markets do not seem to have affected villages as much as climate-related disturbances. Drought and changing seasons have affected agricultural production, particularly from vegetable gardens, resulting in lack of food for most households (as gardens are used mainly for subsistence). Changing seasons and pest invasions have also negatively impacted vegetable gardens and cacao production, affecting household economies that are highly dependent on cacao for monetary revenue.

Based on information provided by villages, low income means less attention is given to health problems, as revenues are first allocated to food needs and education. This could be particularly problematic if climate-related disturbances have also negative health effects on the population. For instance, surveyed results show an increase in malaria outbreaks (59\% of total responses for the category) that could be considered an important impact on human health related to climatic factors. Children also seem to be vulnerable to periods of water scarcity due to increased climate variability; villagers use river water to drink in these dry periods, resulting in stomach problems among children.

\subsection{Social capital for collective action}

The capacity of the system to adapt to current and future changes is continually reshaped through social relationships. Social capital — the 'networks, norms and trust that enable individuals and organisations to act together more effectively to pursue shared objectives' (Putman 1995) — offers a lens through which to study the role of social networks and norms in the development of adaptive capacity 
Table 10. Products traded in different locations and price differences

\begin{tabular}{|c|c|c|c|}
\hline \multirow[t]{2}{*}{ Products } & \multicolumn{3}{|c|}{ Location of trade } \\
\hline & Village market (Mboy II) & Yokadouma market (53km) & Bertoua market (350km) \\
\hline Manioc & $2500 \mathrm{cfa} /$ bucket & 3000-3500cfa/ bucket & 5000-7000cfa/ bucket \\
\hline Plantain & 500cfa/medium size & 1000cfa/medium size & $1500-2000 \mathrm{cfa} /$ medium size \\
\hline Pepper & $6000 \mathrm{cfa} /$ bucket of $15 \mathrm{~L}$ & & \\
\hline Cacao & $700-1150 \mathrm{cfa} / \mathrm{kg}$ & $1000-1300 \mathrm{cfa} / \mathrm{kg}$ & \\
\hline Coffee & 3000-5000cfa/ bucket & 3500-7000cfa/ bucket & \\
\hline Mpeke (Andok or Gnoro) & 1500-2000cfa/ Kombo & & \\
\hline \multirow[t]{2}{*}{ Livestock } & $15000-25000 \mathrm{cfa} /$ goat & & \\
\hline & 15 000-45 000cfa/sheep & & \\
\hline Avocado & 25-100cfa/ piece & & \\
\hline Shrimp & $25000 \mathrm{cfa} /$ bucket & $25000 \mathrm{cfa} /$ bucket & \\
\hline Arki (local alcohol) & $450 \mathrm{cfa} / \mathrm{L}$ & & \\
\hline
\end{tabular}

among collectives (Pelling and High 2005). Social capital and the social dynamics of adaptive capacity are defined by the ability to act collectively, which involves the interdependence of actors through their relationships with each other, with the institutions in which they reside, and with the resource base on which they depend (Adger 2003; Crona and Bodin 2009).

Most of the vulnerability studies in climate adaptation that use social capital focus on assessing the formal organisations in a community or nation (Pelling and High 2005). In a similar way, the analysis of social capital in the villages has captured formal organisations and social infrastructure; this is mainly because they are more visible and easy to assess through the participatory methods applied in the baseline assessment. The analysis used a historical perspective to understand the dynamics of social capital as individuals and communities change and create new local institutions or associations. Social infrastructure and its maintenance were also considered in the analysis as a way to assess the villages' capacity to act collectively for the common good.

Social capital varies across the villages, but in general there is a lack of collective action to take care of social infrastructure. The main concern of villagers seems to be the low level of maintenance allocated to different social infrastructure like health centres, markets and schools where investments have been made. For example, the police station, storage areas and the market hall in Mboy II are in a state of disrepair, although they were built after 2000. Other services such as the local hospital and the secondary school suffer from a lack of trained staff.

There is wide ranging variance in the socio-institutional capital in the villages considered in the baseline assessment. Generally, there is a lack of investment in new skills, training and infrastructure. In addition, there is little maintenance and upkeep of projects intended to benefit the villages as a whole (See Table 11, bad conditions showed in red). Benefits from the Community Forest were only mentioned in Mang, but not all social work was well kept. In most cases, local population is in charge of maintenance, and shows low capacity to act collectively for the common good.

Many of the local associations (GICs) in the villages focus on improving agriculture, reducing the costs of production or managing community forests (see Annex). Most are created to support agriculture, with the aim of making communal fields or introducing alternative production systems to increase revenues. Others aim to facilitate intensive production, livestock breeding, joint purchasing of inputs or joint production. Not all GICs are limited to production; some, which have generally existed for longer periods of time, are focused on education and capacity building. Nevertheless, most GICs have been formed recently. A number of GICs do not seem to have performed any activities in 2010, which suggests they are not very active. With some exceptions, most GICs are small with on average 20 members. The largest revenues to date were generated by the 
Table 11. Summary of social infrastructure in the villages

\begin{tabular}{|c|c|c|c|c|}
\hline Village & Social infrastructure & Construction entity and year & $\begin{array}{l}\text { Maintenance } \\
\text { responsibility }\end{array}$ & Current state \\
\hline \multirow[t]{7}{*}{ Mboy II } & Market at Mboy II & $\begin{array}{l}\text { Rural community Yokadouma } \\
\text { (C.R.Y) in } 2003\end{array}$ & C.R.Y & Neglected \\
\hline & $\begin{array}{l}\text { Frontier police post at } \\
\text { Mboy II }\end{array}$ & $\begin{array}{l}\text { Forestry Society RCA (Sesam) } \\
\text { in } 2001\end{array}$ & Police & Neglected \\
\hline & Hospital at Mboy II & State of Cameroon in 1977 & State/ C.R.Y & Neglected \\
\hline & Military post & Fengeau Marc in 1992 & & Neglected \\
\hline & Catholic church at Mboy & Vatican 2 in 1996 & Christians in Mboy & Regular \\
\hline & Wellat Mboy II & $\begin{array}{l}\text { State of Cameroon and local } \\
\text { population } 2003\end{array}$ & $\begin{array}{l}\text { Population of } \\
\text { Mboy II }\end{array}$ & Broken down \\
\hline & $\begin{array}{l}\text { Public school CES } \\
\text { (secondary level) }\end{array}$ & Council/ State & Mairie/ State & Regular \\
\hline \multirow[t]{3}{*}{ Bompello } & $\begin{array}{l}\text { Building with two } \\
\text { classrooms }\end{array}$ & RFA 1996 & State and APE & Good condition \\
\hline & $\begin{array}{l}\text { Village hall or } \\
\text { community hall }\end{array}$ & RFA 1996 & Population & Good condition \\
\hline & $\begin{array}{l}\text { Generator, satellite dish } \\
\text { and TV }\end{array}$ & 2006 Community Forest & Population & Neglected \\
\hline \multirow[t]{3}{*}{ Massiembo } & Well & State in March 2011 & Population & Broken down \\
\hline & $\begin{array}{l}\text { Village hall or } \\
\text { community hall }\end{array}$ & RFA, 1997 & Population & Good condition \\
\hline & chapel & RFA, 1999 & Population & Good condition \\
\hline \multirow[t]{9}{*}{ Mang } & $\begin{array}{l}\text { Maternity school } \\
\text { Sainte Famille }\end{array}$ & RFA and church 2000 & Population & Good condition \\
\hline & $\begin{array}{l}\text { Village hall or } \\
\text { community hall }\end{array}$ & RFA, 1997 & Population & Bad condition \\
\hline & Well & State and Catholic Mission & Population & Good condition \\
\hline & Satellite dish and TV & RFA, 2006 & Population & Broken down \\
\hline & Chainsaw and brick press & RFA, 1999 & Population & Broken down \\
\hline & Satellite dish and TV & 2006 Forest Community & Population & Neglected \\
\hline & Improved water source & 2006 Forest Community & Population & Good condition \\
\hline & Construction of a classroom & 2006 Forest Community & Population & Not completed \\
\hline & $\begin{array}{l}\text { Contribution to the } \\
\text { construction of a marital } \\
\text { Chapel and Bell }\end{array}$ & 2006 Forest Community & Population & Good condition \\
\hline \multirow[t]{8}{*}{ Mendoungue } & Public school & State & APE & Bad condition \\
\hline & Catholic church & Catholic Mission & Christians & Good condition \\
\hline & EPC & Christians & Christians & Bad condition \\
\hline & Adventist church & Christians & Christians & $\begin{array}{l}\text { Under } \\
\text { construction }\end{array}$ \\
\hline & Improved water source & State & Population & Good condition \\
\hline & Well & Catholic Mission & Catholic Mission & Broken down \\
\hline & Shed & Village & Village & In ruins \\
\hline & Road & State & State & Good condition \\
\hline
\end{tabular}


GIC UFOR, which produced a chili crop with a 2 million CFA profit in 2010; benefit sharing at the community level has not been evident yet.

The main external investors in villages are the elites, the State, the Catholic and Evangelic missions, NGOs and foreign companies (i.e. logging and mining companies). NGOs like SNV, PADER, WWF, OPADE, Edjengui, CIFAD and RICG have worked in villages that are closer to Yokadouma such as Djalobekoe, Mang, Massiembo and Bompelo. Conversely, more distant villages like Mboy II have not benefited from NGOs. In general, NGOs support GICs to improve agricultural production and promote sustainable management of forests and in the villages. Villages with an NGO presence generally appreciated support received from NGOs. In addition to NGOs, villages also mentioned external interventions led by elites, the Church and foreign companies. According to villagers, external companies provide employment for local people, increase revenues and help keep a positive atmosphere in the village. Overall, however, there is little improvement in social welfare due to lack of maintenance of services. For example, the logging company SEBAC opened the road between Libongo and Mboy II, which allowed villagers to sell part of their production in different markets. However, lack of road maintenance has now restricted marketing products to Libongo. Furthermore, employment tends to favour migrants from surrounding areas instead of local communities.

Results from surveyed households showed that climate-related disturbances could have important indirect effects on social infrastructure. These include the deterioration of roads (38\%) and loss of housing or other infrastructure in the villages (37\%) (see Figure 15). In recent years, for example, strong winds have brought down trees that destroyed several houses in the villages and damaged infrastructure and production (e.g. cacao and manioc). If such disturbances are compounded by lack of maintenance capacity and little collective action in the villages to work on social benefits and recovery, then more severe climatic events could generate greater impacts in the future. 


\section{Conclusion: strengthening adaptive capacity}

Based on insights gained through the RBA and feedback received from village representatives, the following five observations can be made about current community vulnerabilities. These findings will help to inform research on adaptive strategy-making and its potential synergies with mitigation. They refer mainly to strengthening adaptive capacity and can be seen as entry points to decision-makers and planners working with communities to contribute to adaptation practice.

- Walking distances to find NTFPs may increase with population growth, expansion of agriculture land and other pressures on forests. NTFPs constitute an important cash safety net for villages in times of low agricultural production or income and seem to be less vulnerable to climate-related disturbances than agriculture. However, they are seasonal, knowledge is required to find them and their commercialisation is not well organised. Villagers mentioned that some sort of cultivation of NTFPs would help improve their availability, cost-effectiveness and time required to collect them. NTFP plantations or improved agroforestry schemes could offer a solution to the competition over NTFPs and livelihood diversification alternatives in the future. Finding ways of improving NTFP processing, storage and commercialisation could also be beneficial, particularly given that all villages have access to markets where demand for NTFP already exists.

- New alternative livelihoods could be introduced to further diversify the economy. Apiculture, aquaculture, production of medicinal plants and livestock were mentioned by villagers as possible activities that could help broaden the livelihood and economic base of the local population; this could prevent dependence on vulnerable sources of subsistence and income in times of increased climate variability.

- Improved agricultural practices could help increase the productivity of current products such as cacao, coffee and garden products. In the villages, farmers have been expanding cultivated land to compensate for production loss caused by changing seasons since the 2000s. As a coping mechanism, villagers decided to cultivate a larger area of land to counteract low productivity and damaged production, as well as to keep producing similar quantities. In some instances, they also developed small associations to coordinate these efforts and improve their agricultural production. Improving yield would prevent expansion of agricultural land at the expense of forests and could help compensate for losses that farmers have faced due to changes in the seasons over the past decade.

- Strengthening collective action would not only help maintain social infrastructure that benefits the village as a whole, but also improve practices that promote more sustainable management of common land and resources such as Community Forests. According to villagers, improving the enforcement of common rules that define practices such as hunting, logging and reforesting would help prevent situations of extreme degradation or risk of forest disappearance as predicted by many households. Common rules could also apply for sharing benefits of these activities in ways that enrich the village as a whole, as opposed to only the management or decision-making entities.

- Discussion and survey results show how villagers perceive deforestation and how forest degradation has progressed over time. Participatory monitoring could not only create awareness, but also empowerment and commitment to improve the future state of forests managed by villagers. Information gathered through this monitoring system would be very valuable for entities that are working in the sites for the conservation of forests and wildlife.

Lessons from past ecological and social dynamics will serve as the basis for building adaptive capacity to climate variability. However, effective adaptation to future climate change requires building adaptive capacity to new situations. In this regard, decisions will require planning for uncertainty; expanding the safety net to achieve a broader livelihood base and access to options; providing more information on 
social and ecological interactions; and enhancing collaboration between actors that have different experiences and knowledge.

In this regard, pilot actions are fertile ground for long-term solutions as long as systemic learning enables reflection and refinement along the way. Therefore, it is important to build the necessary mechanisms to support the learning process and enable experimenting, monitoring and improvement over time. Most of the insights generated through the vulnerability baseline assessment will be combined with more in-depth research to explore future vulnerability, as well as to identify synergies between mitigation and adaptation in the sites. Results from further analysis will generate recommendations to inform decision-making and planning at the local and national levels across the Congo Basin countries. 


\section{References}

Adger, N. 2003 Social capital, collective action and adaptation to climate change. Economic Geography 79(4): 387-404.

Bodin, O. and Crona, B. 2009 The role of social networks in natural resource governance: what relational patterns make a difference? Global Environmental Change 19: 366-374.

Brooks, N. 2003 Vulnerability, risk and adaptation: a conceptual framework. Working Paper 38. Tyndall Centre for Climate Change Research, University of East Anglia, Norwich, UK.

Crona, C. and Bodin, O. 2010 Power asymmetries in small-scale fisheries: a barrier to governance transformability? Ecology and Society 15(4): 32.

Downing, T.E. and Patwardhan, A. 2004 Assessing vulnerability for climate adaptation. In: Lim, B. and Spanger-Siegfried, E. (eds) Adaptation policy frameworks for climate change: developing strategies, policies and measures. Cambridge University Press, Cambridge, UK.

Downing, T.E. et al. 2005 Integrating social vulnerability into water management. NeWater Working Paper No 5. ISBN 91-975238-6-0.

Folke, C., Hahn, T., Olsson, P. and Norberg, J. 2005 Adaptive governance of social-ecological systems. Annual Review of Environment and Resources 30: 441-73.

Fox, S. 2000 Communities of practice, Foucault and actor-network theory. Journal of Management Studies 37 (6): 853-867.

Fussel, H.M. 2004 Co-evolution of the political and conceptual frameworks for climate change vulnerability assessments. In: Bierman, F., Campe, S. and Jacob, K. (eds) Proceedings of the 2002 Berlin conference on the human dimensions of global environmental change 'Knowledge for sustainability transition: the challenge for social science'. Global Governance Project, Berlin, Germany.

Fussel, H.M. 2007 Vulnerability: a generally applicable conceptual framework for climate change research. Global Environmental Change 17(2): 155-167.

Gunderson, L.H., Holling, C.S. and Light, S.S. 1995 Barriers and bridges to renewal of ecosystems and institutions. Columbia University Press, New York.

Kasperson, J.X. and Kasperson, R.E. 2005 The social contours of risk, vol. 1. Earthscan, London.

Locatelli, B., Brockhaus, M., Buck, A. and Thompson I. 2010 Forests and adaptation to climate change: challenges and opportunities.
In: Mery, G., Katila, P., Galloway, G., Alfaro, R.I., Kanninen, M., Lobovikov, M. and Varjo J. (eds) Forest and society: responding to global drivers of change. IUFRO World Series 25, Vienna, Austria.

Luers, A.L., Lobell, D.B., Sklar, L.S., Addams, C.L. and Matson, P.A. 2003 A method for quantifying vulnerability, applied to the agricultural system of the Yaqui Valley, Mexico. Global Environmental Change 13: 255-267.

McCarthy, J.J., Canziani, O.F., Leary, N.A., Dokken, D.J. and White, K.S. (eds) 2001Climate change 2001: impacts, adaptation and vulnerability. Cambridge University Press, Cambridge, UK.

Metzger, M.J., Leemans, R., Schroter, D. 2005. A multidisciplinary multi-scale framework for assessing vulnerabilities to global change. International Journal of Applied Earth Observation and Geoinformation 7: 253-267.

Newig, J., Günther, D. and Pahl-Wostl, C. 2010 Synapses in the network: learning in governance networks in the context of environmental management. Ecology and Society 15(4): 24. http://www.ecologyandsociety.org/ vol15/iss4/art24/

Ostrom, E. 2005 Understanding institutional diversity. Princeton University Press, Bloomington, U.S.

Resilience Alliance (RA) 2010 http://www. resalliance.org/

Rayner, S. and Malone, E.L. 2001 Climate change, poverty and intragenerational equity: the national level. International Journal of Global Environment Issues 1(2): 175-202.

Schiffer, E. 2007 Net-map toolbox http://netmap. wordpress.com/about/

Smit, B. and Wandel, J. 2006 Adaptation, adaptive capacity and vulnerability. Global Environmental Change 16: 282-292.

Turner, B.L. et al. 2003 A framework for vulnerability analysis in sustainability science. Proceedings of the National Academy of Sciences, 100: 8074-8079.

Usongo, L. and Nzooh, Z. 2008 Chapter 9. Sangha Tri-National (TNS) Landscape In: de Wasseige, C., Devers, D., de Marcken, P., Eba’a Atyi, R., Nasi, R. and Mayaux, Ph. (eds), State of the forest 2008. The Congo Basin forest partnership priority landscapes. Publications Office of the European Union, Luxembourg. ISBN 978-92-79-13210-0, doi: 10.2788/32259. 

CIFOR Working Papers contain preliminary or advance research results, significant to tropical forest issues, that need to be published in a timely manner. They are produced to inform and promote discussion. Their content has been internally reviewed but has not undergone the lengthier process of external peer review.

This paper analyses the current vulnerability of local communities to changes in climate in the Tri-National de la Sangha landscape, Cameroon. This assessment creates the basis to evaluate future vulnerability and identify possible adaptation strategies that could be synergistic with mitigation efforts in the site. The assessment used a participatory approach and different dimensions of vulnerability were applied as the lenses for analysis.

The assessment shows important social, ecological and economic changes over the past decades, which have shaped the dynamic vulnerability of villages in the site. Groups, natural resources and activities have differentiated exposure to different climatic disturbances. Agriculture is the most exposed and affected activity by adverse climate-related disturbances such as prolonged and unexpected dry spells and erratic rainfall. Some forest resources are also vulnerable but to less extent. The vulnerability of the communities is mainly defined by the livelihood diversification strategy of households. However, villagers as a whole are highly vulnerable to a changing climate because most of the households in the villages depend on agriculture for their subsistence and economic development.

The low capacity for collective action is another driver of stress. In most of the villages, collective action to maintain social infrastructure is weak, resulting in poor management of common goods that benefit the village as a whole. Collective action mainly emerges when specific households combine efforts to improve their agricultural practices and trade. Hence, strengthening collective action in the villages has the potential to improve practices that promote a more sustainable management of common land and natural resources.

Based on the insights gained through the baseline vulnerability assessment and feedback received from village representatives, certain elements were identified as important entry points in forthcoming analysis of possible climate adaptation strategies. This requires further research within the context of future vulnerability trajectories to promote synergies with climate mitigation.

This research was carried out by CIFOR as part of the CGIAR Research Program on Forests, Trees and Agroforestry. This collaborative program aims to enhance the management and use of forests, agroforestry and tree genetic resources across the landscape from forests to farms. CIFOR leads the program in partnership with Bioversity International, CIRAD (Centre de coopération internationale en recherche agronomique pour le développement), the International Center for Tropical Agriculture and the World Agroforestry Centre.
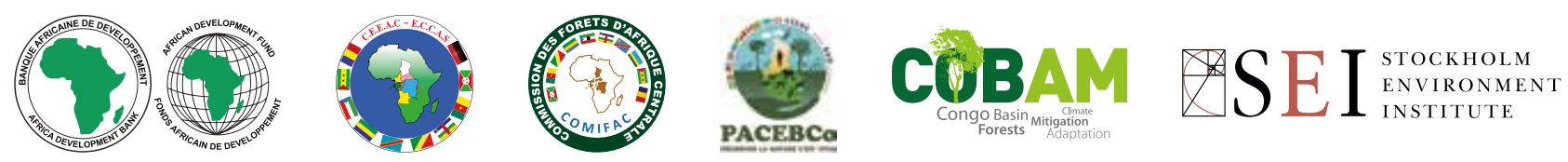

Center for International Forestry Research

CIFOR advances human wellbeing, environmental conservation and equity by conducting research to inform policies and practices that affect forests in developing countries. CIFOR is a CGIAR Consortium Research Center. CIFOR's headquarters are in Bogor, Indonesia. It also has offices in Asia, Africa and South America.

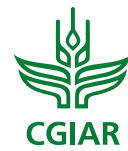

